Prepared for the U.S. Department of Energy under Contract DE-AC06-76RLO 1830

Pacific Northwest National Laboratory Operated for the U.S. Department of Energy by Battelle Memorial Institute

\% Battelle MASTER 
PNNL-11033

UC-810

Project Technical Information

\title{
HWVP Submerged Bed Scrubber Waste Treatment by Ion Exchange at High pH
}

\author{
L. A. Bray \\ K. J. Carson \\ R. J. Elovich \\ D. E. Eakin
}

March 1996

Prepared for

the U.S. Department of Energy

under Contract DE-AC06-76RLO 1830

Pacific Northwest National Laboratory

Richland, Washington 99352 


\title{
DISCLAIMER
}

This report was prepared as an account of work sponsored by an agency of the United States Covernment. Neither the United States Covernment nor any agency thereof, nor Batrelle Memorial institute, nor any of their employees, makes any warranty, express or implied, or assumes any legal liability or responsibility for the accuracy, completeness, or.usefulness of any information, apparafus, product, or process disclosed, or represents that its use would not infringe privately owned rights. Reierence herein to any specific commercial product, process, or service by trade name, trademark, manufacturer, or othenvise dúes not necessarily constitute or imply its endorsement, recommendation, or favoring by the United States Government or any agency thereof, or Battelle Memorial Institute. The views and opinions of authors expressed herein do not necessarily state or reflect those of the United States Government or any agency thereof.

\author{
PACIFIC NORTHWEST NATIONAL LABORATORY \\ operated by \\ BATTELLE \\ for the \\ UNITED STATES DEPARTMENT OF ENERGY \\ under Contract DE-AC06-76RLO 1830
}

\author{
Printed in the Uniled States of America \\ Available to DOE and DOE contractors from the

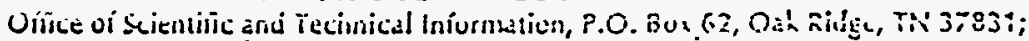 \\ prices, available from (615) $576-8401$. \\ Available to the public from the National Technical Information Service, \\ U.S. Department of Commerce, 5285 Port Royal Rd., Springfield, VA 22161
}


SUMMARY

The Hanford Haste Vitrification Plant (HWVP) is expected to produce aqueous waste streams that will require further processing for cesium, strontium, and transuranic (TRU) removal prior to incorporation into grout. Fluor Daniel, Inc. has recommended that zeol ite be added to these waste streams for adsorption of cesium (Cs) and strontium ( $\mathrm{Sr}$ ) following $\mathrm{pH}$ adjustment by sodium hydroxide $(\mathrm{NaOH})$ addition. Filtration. will then used to remove the TRU elements associated with the process solids and the zeolite containing the $\mathrm{Cs}$ and $\mathrm{Sr}$.

Previous ion exchange tests (Bray et a]. 1990) determined the Cs, Sr, and TRU distribution ratios for three different zeolite sorption materials (IONSIV®A-50, IE-95, and IE-96) as a function of the solution sodium concentration, temperature, and $\mathrm{pH}$. The ion exchange materials used in these previous tests were unbound zeolite crystals without clay binders having a typical. particle size less than 10 microns. The IE-96 zeolite used in the previous tests'was unbounded crystals made by converting unbounded IE-95 crystals by ion exchange on a laboratory scale to produce test quantities of this material. On a commercial scale the granular IE-96 (calcium form) is prepared.by ion exchange conversion of granular IE-95 (sodium form). This ion exchange process is done commercially with the zeolite in the granular form and therefore only the IE-95 can be obtained "commercially" in the original unbounded form. The distribution ratio $\left(R_{d}\right)$, expressed as the ratio of the concentration of the radionuclide exchanged on the solid phase (activity per gram of dry solid) to the concentration of the radionuclide remaining in the liquid after batch contact (activity per $\mathrm{mL}$ of solution), is a measure of the effectiveness of a material's ion-exchange properties. The results of these previous tests showed that the IE-96 zeolite was the most desirable exchanger for HWVP application based primarily for its cesium selectivity.

The current laboratory-scale tests evaluated the impact of high $\mathrm{pH}$ on the adsorption characteristics of IE-96 zeolite granules (including the clay binder) specially ground to pass a 120 mesh sieve ( $<125$ micron) to determine the effect of $\mathrm{pH}$ on $\mathrm{Cs}, \mathrm{Sr}$, and TRU sorption. These tests evaluated the 
potential physical degradation of the zeolite with time at $\mathrm{pH}^{\prime} \mathrm{s}$ up to 13 . The combined effect of precipitation and adsorption on TRU removal was determined. Adsorption tests were conducted at $25^{\circ} \mathrm{C}$ at $\mathrm{pH}^{\prime} \mathrm{s}$ of 9 and 11 to establish a baseline comparison to the previous tests and then at the projected process temperature of $43.3^{\circ} \mathrm{C}\left(110^{\circ} \mathrm{F}\right)$ at $\mathrm{pH}^{\prime} \mathrm{s}$ of $9,11,12$, and 13 . In addition to these laboratory tests, literature pertinent to zeolite degradation at high $\mathrm{pH}$ was reviewed and assessed. The information found in this review would have been used to modify the laboratory tests if there were indications that the approach being taken was not adequate to obtain the desired information.

Based on the literature review, it appeared that some zeolite degradation may occur at high $\mathrm{pH}$ but that it is very slow and should not impact HWVP operation. No changes to the $\mathrm{pH}$ test $\mathrm{plan}$ were made as a result of the 7iterature review.

The results of these laboratory contacts of specialiy ground zeolite at high $\mathrm{pH}$ showed no overall detrimental impact on zeolite degradation as evidenced by $C s$ and $S r$ distribution ratios and visual inspection of the zeolite. Distribution ratios for the key components of $C s$ and $\mathrm{Sr}$ did not decrease with contact times up to 10 days and $\mathrm{pH}^{\prime}$ s up to $\mathrm{pH} \mathrm{13}$, indicating that the zeolite did not deteriorate with time at high $\mathrm{pH}$. The visual inspections found no evidence of zeolite breakdown to smaller particle size, agglomeration into a gelatinous mass, or other noticeable characteristics that could potentially cause problems in pumping; filtering, or handling of the waste stream. There was a significant reduction in $\mathrm{Cs}$ distribution ratio at a $\mathrm{pH}$ of 13 indicating that the increased sodium from the sodium hydroxide used for $\mathrm{pH}$ adjustment was competing for ion exchange sites on the zeolite. This was not a result of zeolite degradation, as it occured at all test times including as short as 1 minute and the distribution ratio increased with time which would not occur if the zeolite was degrading.

Based on the results of these tests there appears to be no operational upper limit on $\mathrm{pH}$ (up to $\mathrm{pH} \mathrm{13)} \mathrm{for} \mathrm{conducting} \mathrm{the} \mathrm{zeolite} \mathrm{contact} \mathrm{of} \mathrm{HWVP}$ waste streams. However, as expected the Cs distribution ratio declined with increased $\mathrm{pH}$ because of the increased $\mathrm{Na}$ to $\mathrm{Cs}$ ratio. which would require additional zeolite to achieve the same level of Cs removal. However, the decline 
in Cs distribution ratio was particularly sharp between $\mathrm{pH} 12$ and 13 (11,700 vs 4,279 at 10 days) so that operation at $\mathrm{pH} 13$ is probably not a desireable process condition. The current design plan to rely on sampling for $\mathrm{pH}$ control should be sufficient to prevent excessive addition of sodium hydroxide.

The cesium distribution ratios were higher for these tests which used specially ground zeolite than for the previous tests which used unbound. zeolite crystals. Although the distribution ratio was higher the actual amount of cesium removed was not that much higher because it was extremely high $(-98 \%)$ in both cases. These results indicate that there are no unsuspected problems associated with the specially ground zeolite.

The measured distribution ratio for TRU ( $A m$ and $P U$ ) were typically very low when both the test sample and the standard were filtered following contact and increased significantly when the standard was not filtered indicating that the TRU was mostly precipitated and that very little additional was adsorped on the zeolite.

The strontium distribution ratio increased with increased $\mathrm{pH}$. 


\section{CONTENTS}

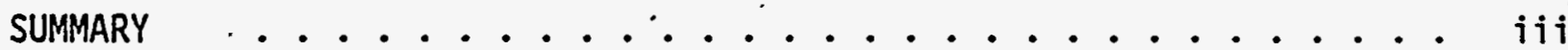

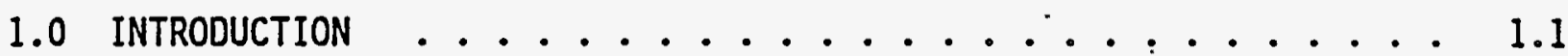

2.0 CONCLUSIONS AND RECOMMENDATIONS $\ldots \ldots . \ldots . \ldots . \ldots . \ldots$

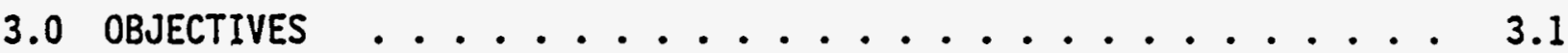

4.0 STUDY APPROACH $\ldots \ldots \ldots \ldots . \ldots \ldots . \ldots . \ldots . \ldots . \ldots$

5.0 TEST EqUIPMENT AND MATERIALS DESCRIPTION $\ldots \ldots . \ldots . . . . .5 .1$

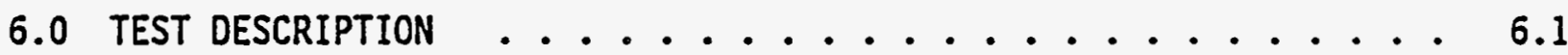

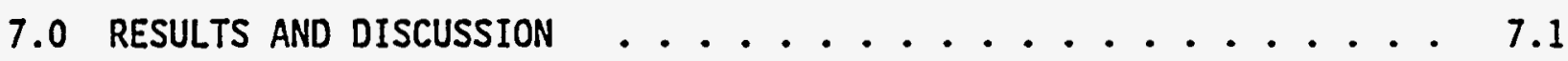

7.1 PHASE I - BASELINE EVALUATION OF ZEOLITE IE-96 $\ldots \ldots \ldots 7.1$

7.2 PHASE 2 - EVALUATION OF HIGH PH ON BOUNDED IE-96 .... 7.4

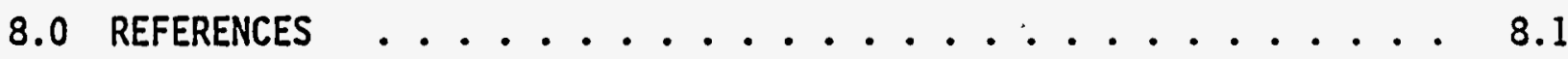

APPENDIX A: ZEOLITE PARTICLE SIZE ANALYSIS . . . . . . . A.1

APPENDIX B: ZEOLITE STABILITY AT HIGH PH ........... B.1 


\section{FIGURES}

7.1 Cesium Distribution Ratio Values for Specially. Ground IE-96 as a Function of Contact Time and $\mathrm{pH} \ldots \ldots . \ldots 7.12$

7.2 Strontium Distribution Ratio Values for Specially Ground IE-96 as a Function of Contact Time and pH ......... 7.13 


\section{TABLES}

4.1 "Target" Test SBS Composition ............... 4.2

4.2 Summary Data Sheet, Temperature, , pH ......... 4.3

5.1 Composition of IE-96 ........................ 5.1

7.1 Anatysis of Test Solutions - Phase 1 .......... 7.2

7.2 Batch Distribution Ratios, $25^{\circ} \mathrm{C}$, Solution \#1, Nominal pH 9 . . 7.4

7.3 Batch Distribution Radios, $25^{\circ} \mathrm{C}$, Solution \#2, Nominal pH 11 . . 7.5

7.4 Comparison Between Previous and Present Hork Using Unbonded Zeolite Crystals (UZC) and Specially Ground IE-96 ....... 7.6.

7.5 Analysis of Test Solutions - Phase 2 . . . . . . . 7.7

7.6 Batch Distribution Ratios, $43.3^{\circ} \mathrm{C}$, Solution \#3, Nominal pH 9 . . 7.8

7.7 Batch Distribution Ratios, $43.3^{\circ} \mathrm{C}$, Solution \#4, Nominal pH 11 . . 7.9

7.8 Batch Distribution Ratios, $43.3^{\circ} \mathrm{C}$, Solution $\# 5$, Nominal pH 12 . 7.10

7.9 Batch Distribution Ratios, $43.3^{\circ} \mathrm{C}$, Solution $\# 6$, pH $13 \ldots 7.11$ 


\subsection{INTRODUCTION}

The Hanford Waste Vitrification Plant (HWVP) is being designed to provide a vitrification facility to immobilize Hanford high-level liquid defense .waste into a borosilicate glass matrix. The high-level waste will be pretreated and transferred to the vitrification facility as a feed. In the HWVP, the waste is concentrated, chemically adjusted to make melter feed, and then converted to glass. The glass product will be sealed in canisters, which are decontaminated, and stored onsite unti] the canisters are shipped to a federal repository. The liquid process wastes generated in HWVP will be incorporated into grout. In order to be incorporated into grout, the process wastes must be nontransuranic (non-TRU) and meet specific requirements for radionuclide (Cs and Sr) content.

Fluor Daniel, Inc., the architect-engineering firm for HWVP recommended that IONSIV IE-96 powdered zeolite be added directly to these solutions to remove the CS and $\mathrm{Sr}$ by ion exchange. Prior to addition of zeolite, the $\mathrm{pH}$ of the waste stream is adjusted which precipitates the TRU elements. 'A pneumatic hydropulse filter (PHP) has been recommended to remove the zeolite containing the $\mathrm{Cs}$ and $\mathrm{Sr}$ and the process solids containing the TRU elements. The solids removed by filtration in HWVP will be recycled to the melter feed system for incorporation into the HWVP glass product.

In FY 1989, the Pacific Northwest Laboratory (PNL) began a test program to evaluate the recovery of $\mathrm{Cs}, \mathrm{Sr}$, and select transuranics (Am and $\mathrm{Pu}$ ) from HWVP process wastes using zeolite ion exchange followed by filtration and to evaluate the Fluor design calculations (Sharp 1988). Results of ion exchange

- tests conducted in FY 1989 (Bray et a7. 1990) showed that the contact of HWVP wastes with unbound zeolite crystals (particle size less than $10^{\circ}$ micron and without binder) would be expected to result in better performance than had been projected by Fluor and that:

- IE-96 was the preferred ion exchanger for CS

- A-50 was the preferred ion exchanger for $\mathrm{Sr}$

- there was no evidence of chemical attack of the ion exchange materials by fluoride and chloride ions 
- at a $\mathrm{pH}>7$ the $\mathrm{Pu}$ and Am solubility is so low that the aqueous concentration will be less than $2 \mathrm{nCi} / \mathrm{g}$ of solution

- the Cs distribution ratio $\left(R_{d}\right)$ for IE-96 could be estimated as $462 /[\mathrm{Na}+] \mathrm{g}-\mathrm{mole} / \mathrm{L}$ which was a factor of almost $1.6 \mathrm{higher}$ than projected by Fluor

- the Cs $R_{d}$ decreased $35 \%$ when the temperature was increased from $25^{\circ} \mathrm{C}$ to the projected operating temperature of $43.3^{\circ} \mathrm{C}\left(110^{\circ} \mathrm{F}\right)$ as compared to the $25 \%$ decrease that was projected. This difference is not expected to impact design calculations because, based on test measurements, the actual $C s R_{d}$ is expected to be about 6000 at a sodium concentration of $0.05 \mathrm{~g}-\mathrm{mol} \mathrm{l} / \mathrm{L}$ and a temperature of $43.7^{\circ} \mathrm{C}$ compared to the fluor projected value of 4417 .

- the measured approach to equilibrium for cesium was $99.7 \%$ at 100 minutes of contact time compared with the Fluor projected removal efficiency of $98.6 \%$ at 135 minutes

- the Cs $R_{d}$ did not vary greatiy over the pH range of 5 to 11

- the $S r R_{d}$ for IE-96 was a factor of 10 less than projected by F7uor, however this is expected to have a minor impact on design because of the relatively low amount of $\mathrm{Sr}$ expected in the waste stream.

The present tests were conducted to determine the impact of high $\mathrm{pH}$ on zeolite adsorption characteristics and potential physical degradation of the zeolite. These activities were directed towards establishing a "pH control methodology" for use in HWVP waste treatment during the zeolite adsorption step. The zeolite used for these tests was IE-96 granules specialiy ground to pass a 120 mesh sieve (<125 micron) and contained the clay binder used to form the zeolite granules from unbound zeolite crystals. In addition to these 1 aboratory tests, a review and assessment of the literature pertinent to zeolite degradation at high $\mathrm{pH}$ was conducted.

This activity conducted by Pacific Northwest Laboratory (PNL) was described in the Hanford Waste Vitrification Applied Technology Plan (WHC-EP-0350) and the FY 91 Statement of Work for Applied Technology Tasks to be Performed by PNL (WHC-SP-0638) under section "Waste Treatment: CWBS 1.2.2.03.06". This report presents the results of zeolite adsorption/ degradation studies to satisfy the requirements of Deliverable C91-03.06C, "Issue Haste Treatment pH Control Methodology Report". 


\subsection{CONCLUSIONS AND RECOMMENDATIONS}

Based on the results of these tests, there appears to be no visual physical degradation or adverse impact over time (up to the maximum contact period of 10 days) on cesium or strontium distribution ratios that would indicate that the specially ground IE-96 zeolite degraded because of high pH. The visual' inspections found no indication of zeolite breakdown to smaller particle size, aggiomeration into gelatinous mass, or any other noticeable characteristics that could potentially cause problems in pumping, filtering, or handling of the waste stream. There appears to be no operational 1 imit resulting from high $\mathrm{pH}$ with respect to zeolite degradation. Distribution ratios for the key components of $\mathrm{Cs}$ and $\mathrm{Sr}$ did not decrease with contact time at all $\mathrm{pH}^{\prime} \mathrm{s}$ including $\mathrm{pH}$ of 13 , indicating that the zeolite did not deteriorate with time because of chemical attack at high $\mathrm{pH}$.

The distribution ratio for cesium decreased as expected as the $\mathrm{pH}$ increased due. to increased sodium from adjusting the $\mathrm{pH}$ with sodium hydroxide. Although the high $\mathrm{pH}$ did not cause degradation of the zeolite, the decrease in distribution ratio when the $\mathrm{pH}$ was increased from 12 to 13 would probably make $\mathrm{pH} 13$ an undesirable process condition. The Cs distribution ratio was reduced to 4,279 at a pH of 13 as measured at. 10 days (temperature $=43.3^{\circ} \mathrm{C}$ ) while it had remained above 11,000 for the other $\mathrm{pH}^{\prime} \mathrm{s}$. This indicates that there was sufficient sodium from the sodium hydroxide added to adjust to this $\mathrm{pH}$ to substantially compete with the cesium. The $\mathrm{Na} / \mathrm{Cs}$ ratios were 121, 165, 187, and 480 for the $\mathrm{pH}^{\prime} \mathrm{s}$ of $9,11,12$, and 13 .

The cesium distribution ratios for the specialiy ground IE-96 measured at $25^{\circ} \mathrm{C}$ were higher than those measured in the previous tests using unbound zeolite crystals. At 1,000 minutes at $\mathrm{pH}$ of 9 , the current tests had a Cs distribution ratio 27,700 as compared to 14,500 in the previous tests. At a $\mathrm{pH} 11$ it was approximately 19,000 as compared to 13,200. A7though this difference may appear large, the difference in cesium removal is actually very sma 71 . At the recommended zeolite concentration of $3.04 \mathrm{~g} / \mathrm{L}$, the $\mathrm{Cs}$ removal efficiencies would be $98.3 \%$ and $97.6 \%$ respectively for distribution ratios of 19,000 and 13,200 . Thus, the specialty ground zeolite used in these tests 
performed better than the zeolite crystals previously used. Although some of this difference can be explained by the lower sodium concentration in the current test solutions, this does not account for the full difference. A full .exploration and explanation of the reason for this difference was beyond the scope of these tests. However, these results indicate that there are no unsuspected problems associated with the specially ground zeolite.

The measured distribution ratio for TRU (Am \& PU) were typicaliy low $(<1,000)$ when both the test sample and the standard were filtered following contact and increased significantly (normally $>10,000$ ) as measured at 10 days when the standard was not filtered indicating that the TRU was mostly precipitated and that very little additional was adsorbed on the zeolite. 


\subsection{QBJECTIVES}

The: primary objective of these tests was to evaluate the overall impact of high pH on specially ground zeolite adsorption characteristics to determine if there is a upper $\mathrm{pH}$ limit for effective performance. Specifically the objectives included the following items:

- evaluation of the effect of high $\mathrm{pH}$ on zeolite adsorption as measured by $\mathrm{Cs}$, Sr, and TRU distribution ratios over time which would indicate degradation.

- Evaluation of the potential physical degradation of the zeolite (breakdown to smaller particles, agglomeration into a gelatinous mass, or other noticeable characteristics that could potentially cause problems in pumping, filtering, or handling of the waste stream) with time at $\mathrm{pH}^{\prime} \mathrm{s}$ up to a $\mathrm{pH}$ of 13 as determined by visual inspection.

- Determination of the combined effect of precipitation and adsorption on TRU removal.

- Establishment of a baseline comparison to the previous tests which used unbound zeolite crystals by conducting adsorption tests at $25^{\circ} \mathrm{C}$ at $\mathrm{pH}^{\prime} \mathrm{s}$ of 9 and $\mathrm{II}$ and then at the projected HWVP temperature of $43.3^{\circ} \mathrm{C}\left(110^{\circ} \mathrm{F}\right)$ at $\mathrm{pH}^{\prime} \mathrm{S}$ of $9,11,12$, and 13 .

Although the $C_{s} R_{d}$ is known to change with the $\mathrm{Na} / \mathrm{Cs}$ ratio, it was not possible to keep the sodium to cesium ratio exactly the same because $\mathrm{NaOH}$ was used for $\mathrm{pH}$ adjustment. However, the objective of these tests was to look at significant changes in adsorption with time (indicating degradation due to $\mathrm{pH}$ ) rather than look at differences between $\mathrm{pH}^{\prime} \mathrm{s}$ which could be attributed to different $\mathrm{Na}$ to $\mathrm{Cs}$ ratios. Also the tests were designed to duplicate as close as possible HWVP conditions where high $\mathrm{pH}$ would result from excess $\mathrm{NaOH}$ addition during neutralization. If either adsorption characteristics or zeolite degradation were impacted substantialiy by high $\mathrm{pH}$, then more stringent $\mathrm{pH}$ measurement/control systems may be required for HWVP design. 


\subsection{STUDY APPROACH}

A simulated HWVP Submerged Bed Scrubber (SBS) solution with the "target" composition shown in Table 4.1 was batch contacted on a laboratory scale with IE-96 zeolite exchange material. This is the same "base case" SBS simulant used in previous ion exchange testing and identified as Target Solution \#1 (Bray et a1. 1990). The simulant was madeup by adding appropriate amounts of salts of the various cations to provide the desired concentrations. Any solids contained. in the test solutions were filtered out prior to addition of the tracers and contact with the zeolite. The specific makeup procedure is included in the Test Instructions for pH Effect on Zeolite Adsorption. IE-96 zeolite in commercially available granules produced by UOP (formerly called Union Carbide Corporation) were obtained and ground to produce a particle size of -120 mesh (<125 micron). The suitability of this zeolite for HWV technology development is discussed in Smith (1991).

Batch distribution ratios $\left(R_{d}\right)$ for $\mathrm{Cs}, \mathrm{Sr}, \mathrm{Pu}$, and Am expressed as the ratio of the concentration of the radionuclide exchanged on the solid phase (activity per gram of dry solid) to the concentration of the radionuclide remaining in the liquid after contact (activity per $\mathrm{mL}$ of solution) were determined. The batch distribution ratios were determined as a function of contact time at 1 min., $10 \mathrm{~min} ., 100 \mathrm{~min} ., 1000 \mathrm{~min} .$, and 10 days. These tests used IE-96 (clay bound commercial granules) specially ground to pass a 120 mesh sieve, whereas the previous ion exchange tests used unbound zeolite crystals with a particle size $<10$ micron.

Adsorption tests were conducted at $25^{\circ} \mathrm{C}$ at $\mathrm{pH}^{\prime} \mathrm{s}$ of 9 and $\mathrm{II}$ for comparison with the results from previous tests. Adsorption tests were then conducted at $\mathrm{pH}^{\prime} \mathrm{s}$ of $9,11,12$, and 13 at $43.3^{\circ} \mathrm{C}$ (the projected HWVP temperature during batch contact). The test matrix is shown in Table 4.2 as a blank summary data sheet. The complete test matrix includes six summary data sheets, one for each of the six combinations of temperature and $\mathrm{pH}$ that were tested ( $\mathrm{pH} 9$ and 11 at $25^{\circ} \mathrm{C}$ and $\mathrm{pH} 9,11,12$, and 13 at $43.3^{\circ} \mathrm{C}$ ).

Also the combined effect of precipitation and adsorption on TRU removal was determined. During the previous tests when Pu and Am were added to 
TABLE 4.1. "Target" Test SBS Composition

Component moles/L

$\mathrm{Na} \quad 2.15 \mathrm{E}-2$

Cs $\quad 3.31 E-4$

Cd $3.65 E-3$

Sr $\quad 8.56 E-6$

A1 $3.71 E-4$

B $\quad 1.29 \mathrm{E}-2$

$\mathrm{Ba} \quad 5.75 \mathrm{E}-6$

Ca 1.30E-4

Cr $\quad 1.44 E-5$

$\mathrm{Cu} \quad 1.73 \mathrm{E}-5$

$\mathrm{Fe} \quad 7.75 \mathrm{E}-4$

$\mathrm{Mg} \quad 1.73 \mathrm{E}-4$

$\mathrm{Mn} \quad 1.64 \mathrm{E}-5$

$\mathrm{Ni} \quad 6.81 \mathrm{E}-5$

$\mathrm{Rb} \quad 3.98 \mathrm{E}-6$

Si $\quad 7.83 E-3$

$\mathrm{NO}_{3} \quad 6.93 \mathrm{E}-3$

$\mathrm{NO}_{2} \quad 6.96 \mathrm{E}-4$

F $\quad 1.74 \mathrm{E}-2$

C1 $4.80 \mathrm{E}-3$

$\mathrm{SO}_{4} \quad 1.69 \mathrm{E}-3$ 
TABLE 4.2. Summary Data Sheet, Temperature , pH

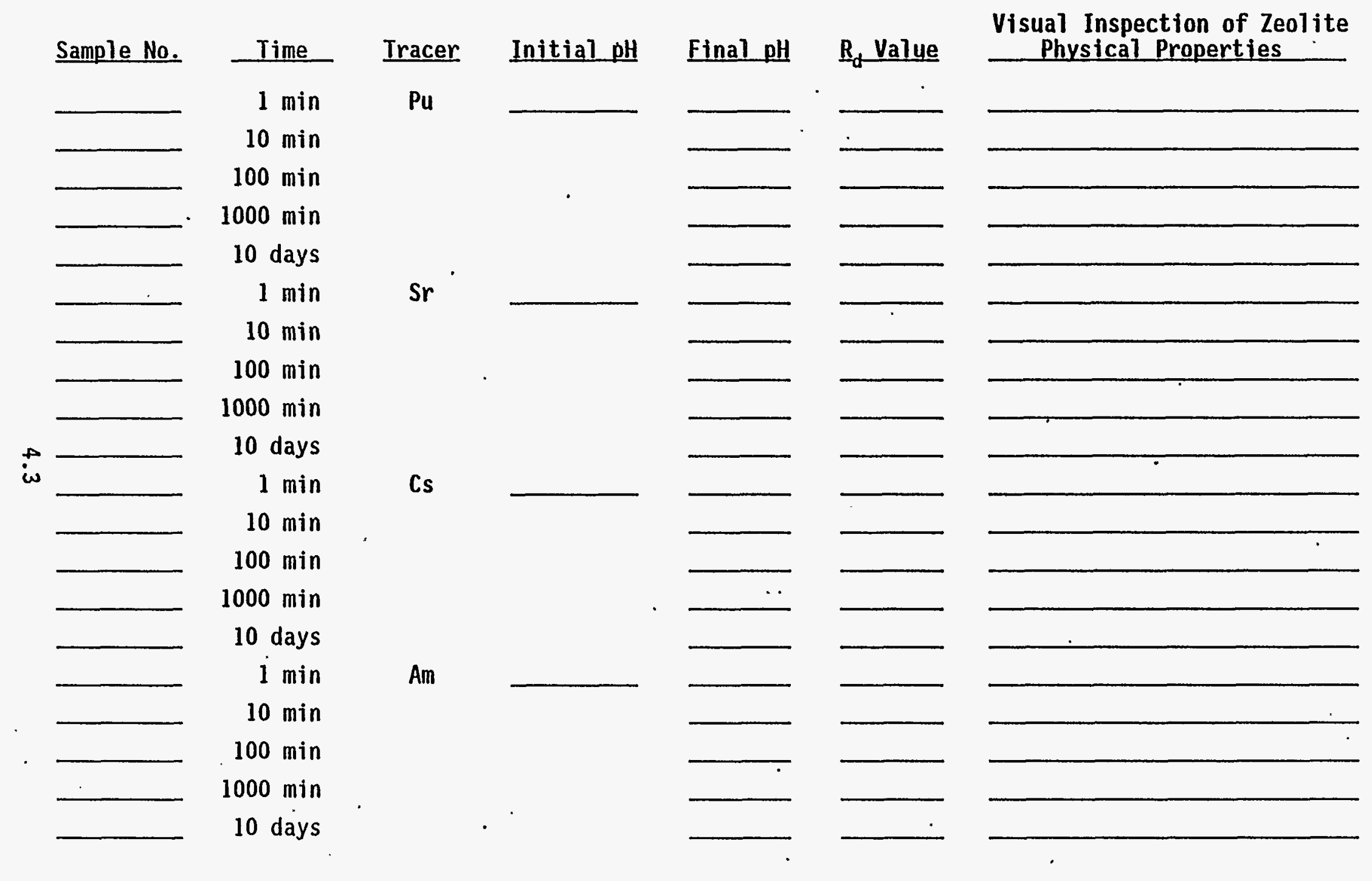


filtered solutions above a pH of 6.5, equilibrated and refiltered, the amount of actinide remaining in solution was not enough to provide an adequate count rate for accurate batch distribution ratio determinations. Therefore, it was not known if the TRU removal was limited by solubility in the final solution - or by adsorption onto the zeolite. In the current tests, the solution was not refiltered after actinide addition and prior to zeolite contact. The resulting TRU concentration in the solution following contact was measured to determine the overalT TRU removal expected due to both precipitation and adsorption. With these exceptions all other conditions such as simulant makeup, method of neutralization, amount of zeolite added, test equipment, radioactive tracers, etc. were the same as for the previous tests.

The degradation of the zeolite was determined by looking for a substantial decline in the distribution ratio, a significant change in solution $\mathrm{pH}$, or changes in the physical properties of the zeolite over time. Changes in the physical properties were determined by visual inspection of the zeolite and provide an assessment of zeolite breakdown to smaller particle size, agglomeration into a gelatinous mass, or other noticeable characteristics that could potentially cause problems in pumping, filtering, or handling of the waste stream.

In addition to these laboratory tests, literature pertinent to zeolite degradation at high $\mathrm{pH}$ was reviewed and assessed. The information obtained during this review would have been used to modify the laboratory tests, if information would have been found to conclude that the approach being taken would not result in obtaining the desired information or that existing information already showed that high $\mathrm{pH}$ was definitely detrimental to the IE-96 zeolite. 


\subsection{TEST EQUIPMENT AND MATERIALS DESCRIPTION}

The experimental equipment, materials, and test solutions are described in this section.

The equipment consisted of a temperature controlled test chamber placed on a mechanical shaker, analytical balance, gamma counting equipment, and an a]pha liquid scintillation counter.

Gamma counting was performed by use of a multichannel analyzer and a detector (i.e., Canberra 40 analyzer and a $\mathrm{NaI}$ well crystal). Alpha tracers were counted using a liquid scintillation counting system (i.e., Packard. United Technologies, Trii-Carb \# 4000). The equipment was user calibrated, using known standards, to determine that the equipment was working properly each time test solutions were analyzed.

Commercial IE-96 zeolite was purchased from UOP (formerly Union Carbide Corp.) (Lot No. 939681090001) and ground to pass a 120 mesh sieve (<125 micron). A particle size analysis by a Brinkman Particle Size Analyzer (PNL Fuels and Control Sample Analysis, Lab. Serial No. Q8435) following grinding showed an average particle size of about 40 micron based on particle volume. The complete analysis of the specially ground zeolite particle size is given in Appendix A. The IE-96 zeotite chemical composition including the clay binder is shown in Table 5.1 .

TABLE 5.1. Composition of IE-96 (Includes C7ay Binder)

\begin{tabular}{lll}
\cline { 1 - 1 } Component & & wt\% \\
\cline { 1 - 1 } $\mathrm{SiO}_{2}$ & & 68.23 \\
$\mathrm{Al}_{2} \mathrm{O}_{3}$ & & 17.17 \\
$\mathrm{Na}_{2} \mathrm{O}$ & & 8.28 \\
$\mathrm{~K}_{2} \mathrm{O}$ & & 0.46 \\
$\mathrm{MgO}$ & & 0.75 \\
$\mathrm{CaO}$ & & 0.81 \\
$\mathrm{Fe}_{2} \mathrm{O}_{3}$ & & 3.83 \\
$\mathrm{TiO}_{2}$ & & 0.47
\end{tabular}

5.1 


\subsection{IEST DESCRIPTION}

The general procedures for batch distribution ratio measurements are described in this section. The study was completed to obtain distribution data for IE-96 zeolite as a function of contact time, temperature, and $\mathrm{pH}$. The primary purpose being to determine the impact of high $\mathrm{pH}$ on zeolite adsorption and potential degradation. The combined effect of precipitation and adsorption on TRU ( $\mathrm{Am}$ and $\mathrm{Pu}$ ) removal was also evaluated by not filtering the test solution following addition of the Am and Pu tracers as had been done in the previous tests.

A batch distribution ratio is a measure of the overall ability of the solid phase to remove an ion from solution. The data in this report are reported as radionuclide distribution ratios $\left(R_{d}\right)$ rather than distribution coefficients $\left(K_{d}\right) . \quad R_{d}$ is reported as $m L$ of solution/g of anhydrous zeolite. To convert to $K_{d}$ (a unitless value) the $R_{d}$ value can be multiplied by the specific gravity of the dry exchanger. The formula for the determination of $R_{d}$ is:

$$
R_{d}=C_{s} \div C_{l}, \mathrm{~mL} / \mathrm{g}
$$

where: $C_{s}=$ the concentration of the radionuclide exchanged on the solid phase ( $\mathrm{C} i$ or $g$ of radionuclide/g of anhydrous zeolite)

$C_{1}=$ the concentration of the radionuclide remaining in the 1 iquid phase after batch contact ( $\mathrm{C} i$ or $\mathrm{g}$ of radionuclide/mL).

The SBS simulant was prepared using the salt of each cation and $\mathrm{pH}$ adjusted using $\mathrm{NaOH}$ to obtain the desired initial $\mathrm{pH}$ and filtered. This solution was then analyzed to determine the actual composition of the test solution in comparison to the target solution. Portions of the SBS simulant were individually traced with the appropriate radionuclide $\left({ }^{137} \mathrm{Cs},{ }^{85} \mathrm{Sr},{ }^{239} \mathrm{Pu}\right.$ or $\left.{ }^{241} \mathrm{Am}\right)$. Samples of the ground zeolite material $(0.1 \pm 0.05 \mathrm{~g})$ were weighed out on a five-place analytical balance and placed in a labeled screw cap $20 \mathrm{~mL}$ glass vial. A $1 \pm 0.5 \mathrm{~g}$ sample of similar material was dried at $105 \pm 10^{\circ} \mathrm{C}$ for $24 \mathrm{~h}$ and cooled in a desiccator before being reweighed to determine the "dry" 
weight correction factor. Ten milliliters of radionuclide spiked aqueous solution was added to each bottle. The bottle was then tightly capped.

The test period was started when the prepared-samples were initially mixed and placed in the temperature controlled test chamber on a mechanical shaker for continuous agitation. The temperature was monitored using a calibrated digital probe. A sample of the feed was placed in a similar bottle and treated as a "standard" sample. Each "standard" contained 5 to $20 \mathrm{~mL}$ of radionuclide-spiked solution without the zeolite. The standard was sampled, filtered and counted with the other samples. This feed blank represents the feed solution prior to contact with the solid exchanger.

The samples were individually removed from the temperature controlled test chamber and quickly filtered using a Gelman \#4192, $0.2 \mu \mathrm{m}$ pore size disposable filter. After filtration, the samples were allowed to come to laboratory room temperature before sampling. For gamma counting, a $4 \mathrm{~mL}$ sample was taken and counted for 2 to 20 minutes, depending on the count rate. The a)pha containing samples were counted using liquid scintillation techniques. The distribution ratio was then calculated based on the count remaining in the test sample as compared to the standard. 


\subsection{RESULTS AND DISCUSSION}

Prior to conducting the Taboratory tests, literature pertinent to zeolite degradation at high $\mathrm{pH}$ was reviewed and assessed. This literature review is included in Appendix B. Based on this review it appears that some zeolite degradation may occur at high pH values, but that it is very slow (requiring weeks) and should not impact HWVP operation. Therefore, there were no changes to the $\mathrm{pH}$ test $\mathrm{plan}$ as a result of this 1 iterature review.

Tests used specially ground zeolite granules including clay binder to determine adsorption characteristics for $\mathrm{Cs}, \mathrm{Sr}$, Am and $\mathrm{Pu}$ as a function of time and $\mathrm{pH}$. The work was completed in two phases: the first phase was conducted at $25^{\circ} \mathrm{C}$ to establish a comparison between these tests and the previous test (Bray et al. 1990) which used unbound zeolite crystals and the second phase was conducted at $43.3^{\circ} \mathrm{C}$ (the projected HWVP condition). The results of these two phases are discussed below.

\subsection{PHASE 1 - BASELINE EVALUATION OF ZEOLITE IE-96}

The initial study by Bray (1990) evaluated several zeolitic materials for the recovery of $\mathrm{Cs}, \mathrm{Sr}, \mathrm{Pu}$, and Am. Unbounded zeolite crystals (IONSIV IE-96) was selected and was found to perform better for Cs removal than projected by Fluor Daniel, Inc. (Sharp 1988). The primary objective of this study was to use specially ground bounded IONSIV IE-96 and to evaluate the impact of high $\mathrm{pH}$ on zeolite adsorption characteristics to determine if there is a upper pH Timit for effective adsorption. Phase 1 teșts were conducted at $25^{\circ} \mathrm{C}$ at $\mathrm{pH}$ values of 9 and 11 to establish a baseline comparison to the previous tests.

A synthetic SBS waste stream was identified for use in the testing program (Table 4.1). The solution was divided into two fractions and adjusted to either a pH of 9 or 11. The solutions were filtered and anaiyzed (Solutions \#I and \#2) prior to the introduction of radiotracers, Table $7: 1$. In general the test solutions were fairly close in composition to the target initial makeup with a few exceptions. There was some discrepancies for minor 
TABLE 7.1. Analysis of Test Solutions - Phase 1

\begin{tabular}{|c|c|c|c|}
\hline \multirow{2}{*}{ Component } & \multirow{2}{*}{$\begin{array}{l}\text { Initial Make-up, } \\
\text { moles } / L\end{array}$} & \multicolumn{2}{|c|}{$\begin{array}{l}\text { Analyzed Composition of } \\
\text { Test Solutions, moles } / L\end{array}$} \\
\hline & & Solution \#1 & Solution \#2 \\
\hline $\mathrm{Na}$ & $2.15 E-2$ & $2.8 E-2$ & $3.9 E-2$ \\
\hline Cs & $3.31 E-4$ & $2.9 E-4$ & $2.9 E-4$ \\
\hline$K$ & $5.63 E-6$ & 2.7E-5 & $3.5 E-5$ \\
\hline $\mathrm{Cd}$ & $3.65 E-3$ & $5.6 E-4$ & $6.0 \mathrm{E}-7$ \\
\hline$S r$ & $8.56 E-6$ & $5.8 \mathrm{E}-7$ & $1.0 E-6$ \\
\hline A1 & $3.71 E-4$ & $\mathrm{BD}$ & $B D$ \\
\hline B & $1.29 E-2$ & $9.3 E-3$ & $1.4 \mathrm{E}-2$ \\
\hline $\mathrm{Ba}$ & $5.75 E-6$ & $5.3 E-7$ & $3.1 E-7$ \\
\hline $\mathrm{Ca}$ & $1.30 \mathrm{E}-4$ & $5.2 E-5$ & $4.0 E-5$ \\
\hline $\mathrm{Cr}$ & $1.44 \mathrm{E}-5$ & $B D$ & $B D$ \\
\hline $\mathrm{Cu}$ & $1.73 E-5$ & $B D$ & $9.4 \mathrm{E}-8$ \\
\hline $\mathrm{Fe}$ & $7.75 E-4$ & $2.8 \mathrm{E}-5$ & $\mathrm{BD}$ \\
\hline $\mathrm{Mg}$ & $1.73 E-4$ & $1.5 E-4$ & $5.6 E-5$ \\
\hline$M n$ & $1.64 E-5$ & $1.4 \mathrm{E}-5$ & $\mathrm{BD}$ \\
\hline $\mathrm{Ni}$ & $6.81 E-5$ & $2.0 E-6$ & $B D$ \\
\hline $\mathrm{Rb}$ & $3.98 \mathrm{E}-6$ & ND & ND \\
\hline Si & $7.83 E-3$ & 5.7E-6 & $3.8 E-5$ \\
\hline $\begin{array}{l}\mathrm{Na} / \mathrm{Cs} \text { Mole } \\
\text { Ratio }\end{array}$ & 65 & 97 & 134 \\
\hline $\mathrm{NO}_{3}$ & $6.93 E-3$ & $5.8 \mathrm{E}-3$ & $5.6 E-3$ \\
\hline $\mathrm{NO}_{2}$ & $6.96 E-4$ & $6.1 E-4$ & $6.1 E-4$ \\
\hline$F$ & $1.74 E-2$ & 1.3E-2 & $1.3 \mathrm{E}-2$ \\
\hline $\mathrm{Cl}$ & $4.80 E-3$ & $4.5 E-3$ & $4.5 E-3$ \\
\hline $\mathrm{SO}_{4}$ & $1.69 \mathrm{E}-3$ & $1.4 \mathrm{E}-3$ & $1.5 \mathrm{E}-3$ \\
\hline
\end{tabular}


components such as $\mathrm{Cr}, \mathrm{Cu}, \mathrm{Ba}$ and $\mathrm{R}_{\mathrm{b}}$. which would not be expected to have an impact on the test results. Other discrepancies such as those for $\mathrm{Cd}, \mathrm{AT}$, $\mathrm{Fe}, \mathrm{Si}$ and $\mathrm{Sr}$ are expected to be as a result of precipitation which would be expected at these $\mathrm{pH}$ conditions and would a7so be expected in. HWVP. Batch distribution ratio $\left(R_{d}\right)$ values were determined for $\mathrm{Pu}$ and $\mathrm{Am}$ (Tables 7.2 and 7.3) without refiltering the solutions following addition of tracers to remove insoluble radiotracers. Normally, both the test sample and the standard (without zeolite) were then filtered at the end of the contact period as described in the "Test Description" section. However, -plutonium and americium $R_{d}$ values are shown based on both filtered and unfiltered standards. The distribution ratio is calculated by comparing the amount of tracer remaining in the filtered test. sample to that in the standard. The large increase in $\mathrm{Pu}$ and Am distribution ratios between the unfiltered and filtered standards indicate that the majority of the plutonium and americium precipitates at these $\mathrm{pH}$ values. The Pu and Am distribution ratios were not previously reported (Bray 1990) and are of questionable value in this report because of the large quantity of TRU precipitated. No major differences were found between previous and present cesium and strontium distribution ratios using unbounded zeolite crystals and bounded IE-96 that had been specially ground, Table T.4. Although the differences in the cesium distribution ratios may appear to be great, the difference in terms of cesium removal is actually quite small because of the relatively large distribution ratios involved. At the recommended zeolite concentration of $3.04 \mathrm{~g} / \mathrm{L}$, the Cs removal efficiencies would be $98.3 \%$ and $97.6 \%$ respectively for distribution ratios of 19,000 and 13,200 . Thus, the specially ground zeolite used in these tests performed better than the zeolite crystals previously used. Although some of this difference can be explained by the lower sodium concentration in the current tests, this does not account for the full difference. A full exploration and explanation of the reason for this difference was beyond the scope of these tests. However, these results indicate that there are no unsuspected problems associated with the specially ground zeolite. 
TABLE 7.2. 'Batch Distribution Ratios, $25^{\circ} \mathrm{C}$, Solution \#1, Nominal pH 9

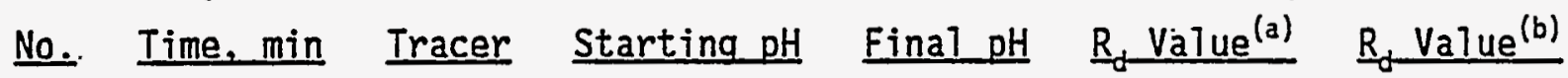

\begin{tabular}{|c|c|c|c|c|c|}
\hline $\begin{array}{cc}1 & 1 \\
2 & 10 \\
3 & 100 \\
4 & 1000 \\
5 & 10 \text { days }\end{array}$ & $\mathrm{Pu}$ & 8.81 & $\begin{array}{l}8.77 \\
8.79 \\
8.80 \\
8.81 \\
8.81\end{array}$ & $\begin{array}{r}215 \\
62 \\
83 \\
108 \\
<1\end{array}$ & $\begin{array}{l}1.6 E 5 \\
8.1 E 4 \\
9.1 E 4 \\
1.0 E 5 \\
2.1 E 4\end{array}$ \\
\hline $\begin{array}{c}1 \\
10 \\
100 \\
1000 \\
10 \text { days }\end{array}$ & $\mathrm{Sr}$ & 8.06 & $\begin{array}{l}7.77 \\
7.76 \\
7.77 \\
7.77 \\
8.14\end{array}$ & $\begin{array}{r}600 \\
994 \\
1,536 \\
1,786 \\
1,378\end{array}$ & \\
\hline $\begin{array}{c}1 \\
10 \\
100 \\
1000 \\
10 \text { days }\end{array}$ & Cs & $8: 85$ & $\begin{array}{l}8.65 \\
8.71 \\
8.71 \\
8.74 \\
8.78\end{array}$ & $\begin{array}{l}9,320 \\
18,300 \\
23,600 \\
27,700 \\
24,300\end{array}$ & \\
\hline $\begin{array}{c}1 \\
10 \\
100 \\
1000 \\
10 \text { days }\end{array}$ & Am & 8.80 & $\begin{array}{l}8.79 \\
8.79 \\
8.76 \\
8.80 \\
8.80\end{array}$ & $\begin{array}{r}<1 \\
<1 \\
<1 \\
409 \\
203\end{array}$ & $\begin{array}{l}4.4 E 4 \\
1.3 E 5 \\
2.0 E 4 \\
6.3 E 5 \\
3.6 E 4\end{array}$ \\
\hline
\end{tabular}

(a) Standard filtered and sample following contact filtered.

(b) Unfiltered standard and filtered sample. following contact.

\subsection{PHASE 2 - EVALUATION OF HIGH PH ON BOUNDED IE-96}

The primary objective of this work was to evaluate the impact of high $\mathrm{pH}$ solutions on zeolite adsorption characteristics and to determine if there is an upper pH limit for effective adsorption. Batch distribution tests from one minute to 10 days were completed using a projected HWVP temperature of $43.3^{\circ} \mathrm{C}$ at $\mathrm{pH}$ value of $9,11,12$, and 13 . No adverse results were obtained in the $\mathrm{pH}$ range from 9 to 13. As expected, the cesium distribution ratios were reduced as the $\mathrm{Na} / \mathrm{Cs}$ mole ratio increased with increasing $\mathrm{pH}$.

A synthetic waste was identified for used in Phase 2 of the testing program (see Table 4.1). The solution was divided into four fractions and adjusted to $\mathrm{pH}$ values of $9,11,12$ and 13 . The solutions were filtered and 
TABLE 7.3. Batch Distribution Ratios, $25^{\circ} \mathrm{C}$, Solution \#2, Nominal pH 11

No. Time, min Tracer Starting pH Final pH $\underline{R}_{d} V_{a l u e}^{(a)} \quad R_{d} V_{a}{ }^{(b e} e^{(b)}$

$\begin{array}{rccrrrr}21 & 1 & \text { Pu } & 10.26 & 10.03 & <1 & 2,350 \\ 22 & 10 & & & 10.01 & <1 & 2,159 \\ 23 & 100 & & & 9.95 & 13 & 1,857 \\ 24 & 1000 & & & 9.89 & 22 & 1,995 \\ 25 & 10 \text { days } & & & 9.82 & 107 & 4,536 \\ 26 & 1 & \text { Sr } & 10.36 & 10.01 & 1,066 & \\ 27 & 10 & & & 9.94 & 1,992 & \\ 28 & 100 & & & 9.79 & 2,722 & . \\ 29 & 1000 & & & 9.85 & 2,777 & \\ 30 & 10 \text { days } & & & 9.87 & 3,120 & \\ 31 & 1 & \text { Cs } & 10.43 & 10.01 & 7,380 & \\ 32 & 10 & & & 9.87 & 15,000 & \\ 33 & 100 & & & 9.91 & 18,500 & \\ 34 & 1000 & & & 9.88 & 487,000 & \\ 35 & 10 \text { days } & & & 9.92 & 19,900 & \\ 36 & & & & & \\ 37 & 10 & \text { Am } & 10.40 & 10.10 & 63 & 279 \\ 38 & 100 & & & 10.00 & 68 & 301 \\ 39 & 1000 & & & 9.99 & 112 & 413 \\ 40 & 10 \text { days } & & & 10.00 & -. & - \\ & & & 9.91 & 165 & 518\end{array}$

(a) Standard filtered and sample following contact filtered.

(b) Unfiltered standard and filtered sample following contact.

analyzed (Solutions $\# 3, \# 4, \# 5$ and $\# 6$ ) prior to introduction of radiotracers, Table 7.5. The differences in the analyzed test solution compositions and the "target" initial makeup are primarily due to precipitation of components which would be expected at high $\mathrm{pH}$. Batch distribution ratio (Rd) values were determined for $\mathrm{Sr}, \mathrm{Cs}, \mathrm{Pu}$ and $\mathrm{Am}$ (Tábles 7.6, 7.7, 7.8, and 7.9) without refiltering the solutions to remove insoluble radiotracers. Plutonium and americium $R_{d}$ results were not previously reported (Bray 1990) and are of questionable value in this report because the TRU's are largely precipitated rather than adsorbed onto the zeolite.

The results from these tests and the previous tests (Bray et al. 1990) using synthetic SBS for the purpose of conducting ion exchange tests would 
TABLE 7.4. Comparison Between Previous and Present Work Using Unbounded Zeolite Crystals (UZC) and Special7y Ground IE-96

Nominal pH: 9 to 9.5

$$
\begin{array}{ll}
\text { Solution } \# 1 D^{(a)} & \text { Solution } \# 1^{(b)} \\
\mathrm{Na} / \mathrm{Cs}: 116 & \mathrm{Na} / \mathrm{CS}: 97 \\
\text { Sr: } 2.4 \mathrm{E}-6 \mathrm{M} & \mathrm{Sr}: 5.8 \mathrm{E}-7 \mathrm{M}
\end{array}
$$

Sample Numbers $\underline{\underline{\text { UZC (a) }} \text { IE-96 }}$

$\begin{array}{crc}369 & 6 & 1 \\ 370 & 7 & 10 \\ 371 & 8 & 100 \\ 372 & 9 & 1000 \\ -- & 10 & 10 \text { days } \\ 373 & 11 & \\ 374 & 12 & 1 \\ 375 & 13 & 100 \\ 376 & 14 & 1000 \\ -- & 15 & 10 \text { days }\end{array}$

Nominal pH: 11 to 11.5
UZC (IE-96) Final pH $\mathrm{R}_{\text {d Value }}$

\begin{tabular}{rr}
9.3 & 1,068 \\
9.1 & 1,297 \\
9.3 & 1,300 \\
9.3 & 1,794 \\
-- & -- \\
9.0 & 8,733 \\
9.3 & 10,858 \\
9.1 & 11,661 \\
9.3 & 14,513 \\
\hline- & --
\end{tabular}

Solution \#1E $\mathrm{E}^{(\mathrm{a})}$ $\mathrm{Na} / \mathrm{Cs}$ : 148 Sr: $4.0 E-6 \underline{M}$
IE-96

Speciai7ly Ground Final pH $\mathrm{R}_{d}$ Value

$\begin{array}{rr}7.8 & 600 \\ 7.8 & 994 \\ 7.8 & 1,536 \\ 7.8 & 1,786 \\ 8.1 & 1,378\end{array}$
8.7
8.7
9,320
$8.7 \quad 18,300$
$8.7 \cdot 27,700$
$8.8-24,300$

Solution $\#^{(b)}$

$\mathrm{Na} / \mathrm{Cs}: 134$

Sr: $1.0 \mathrm{E}-6 \mathrm{M}$
Sample Numbers UZC ${ }^{(a)}$ IE-96(D) $385 \quad 26$ 386

387

388

-. 30

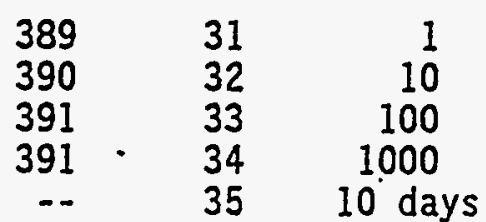
Time, min. Tracer Fina] $\frac{\text { UZC }(I E-96)}{R_{d} \text { Value }}$ $\mathrm{Sr}$ Cs

$\begin{array}{crr}\text { Sr } & 11.0 & 1,203 \\ & 10.9 & 1,460 \\ & 10.2 & 1,724 \\ & 9.9 & 2,128 \\ & -- & -- \\ & & \\ \text { Cs } & 10.8 & 7,777 \\ & 10.2 & 9,431 \\ & 10.1 & 10,976 \\ & 10.9 & 13,119 \\ --- & --\end{array}$

\section{IE-96}

Specially Ground Final pH $R_{d}$ Value

10.0 1,066 1,992 2,722 2,777 3,120

10.0

9.9

9.9

9.9

9.9
7,380
15,000
18,500
19,900

(a) Reference 1 HWVP-90-1.2.2.04.04A, Table C.I, page C.I.

(b) This document Tabies 7.2 and 7.3 . 
TABLE 7.5. Analysis of Test Solutions -- Phase 2

Initial

Component Make-up $\begin{gathered}\text { Analyzed Composition of Test Solutions, moles/L } \\ \text { molution } \# 3 \text { Solution } \# 4 \text { Solution } \# 5 \text { Solution } \# 6\end{gathered}$

$\mathrm{Na}$

$2.15 E-2 \quad 3.35 E-2$

$4.22 E-2$

4.78E-2

1.30E-1

Cs

$3.31 E-4$

2.78E-4

2.55E-4

2.55E-4

2.71E-4

$\mathrm{K}$

5.63E-6

$1.0 E-4$

$1.3 \mathrm{E}-4$

$1.0 \mathrm{E}-4$

2.1E-4

Cd

3. $65 E-3$

4.9E-4

$8.5 E-7$

4. $4 \mathrm{E}-7$

$6.0 \mathrm{E}-6$

$\mathrm{Sr}$

8.56E-6

9.6E-6

9.6E-6

9. $6 \mathrm{E}-6$

9. $6 \mathrm{E}-6$

A1

$3.71 E-4$

$<1.85 E-6$

1.3E-4

2. $5 \mathrm{E}-4$

2. $6 \mathrm{E}-4$

B

1.29E-2

1.OE-2

1.2E-2

1.2E-2

1.2E-2

$\mathrm{Ba}$

5.75E-6

8.0E-7

$6.8 \mathrm{E}-7$

6.7E-7

$6.8 \mathrm{E}-7$

$\mathrm{Ca}$

1.30E-4

7.2E-5

1.44E-5

BD

$6.5 E-5$

5.2E-5

3. $5 E-5$

$\mathrm{Cr}$

1.73E-5

BD

BD

BD

BD

$\mathrm{Cu}$

7.75E-4

1.87E-5

BD

$1.73 E-4$

1.7E-4

1.8E-7

$B D$

3.1E-7

$\mathrm{Mg}$

$1.64 E-5$

8.2E-6

2. $0 E-5$

1.8E-7

9.0E-7

Mn

$6.81 E-5$

$B D$

$<1.8 \mathrm{E}-7$

$<2.5 E-6$

$<2.5 \mathrm{E}-6$

$\mathrm{Ni}$

$3.98 E-6$

ND

$\mathrm{BD}$

$<1.8 \mathrm{E}-7$

$<1.8 E-7$

$\mathrm{Rb}$

$7.83 E-3$

7.1E-6

ND

BD

$B D$

Si

65

$\mathrm{Na} / \mathrm{Cs}$ Mote

Ratio

$\mathrm{NO}_{3}$

$6.93 \mathrm{E}-3$

121

1.8E-5

165

ND

1.1E-4

ND

187

1. $6 \mathrm{E}-4$

480

$\mathrm{NO}_{2}$

$6.96 \mathrm{E}-4$

$9.5 E-3$

9.5E-3

$9.5 E-3$

9. $5 E-3$

$F$

1.74E-2

$6.5 \mathrm{E}-4$

$6.5 \mathrm{E}-4$

$6.5 E-4$

$6.5 \mathrm{E}-4$

1.5E-2

1.5E-2

1.5E-2

C1

$4.80 \mathrm{E}-3$

4. $9 \mathrm{E}-3$

$4.9 \mathrm{E}-3$

$4.9 \mathrm{E}-3$

4. $9 \mathrm{E}-3$

$\mathrm{SO}_{4}$

1. $69 \mathrm{E}-3$

1. $4 \mathrm{E}-3$

$1.6 \mathrm{E}-3$.

1. $6 \mathrm{E}-3$

1. $6 \mathrm{E}-3$

$B D=$ below detection limit.

$\mathrm{ND}=$ not determined. 
TABLE 7.6. Batch Distribution Ratios, $43.3^{\circ} \mathrm{C}$, Solution $\# 3$, Nominal pH 9 No. Time, min Tracer Starting $\mathrm{pH}$ Final $\mathrm{pH} \quad \mathrm{R}_{d} \mathrm{Value}^{(\mathrm{a})} \mathrm{R}_{\mathrm{d}} \mathrm{Value}^{(\mathrm{b})}$

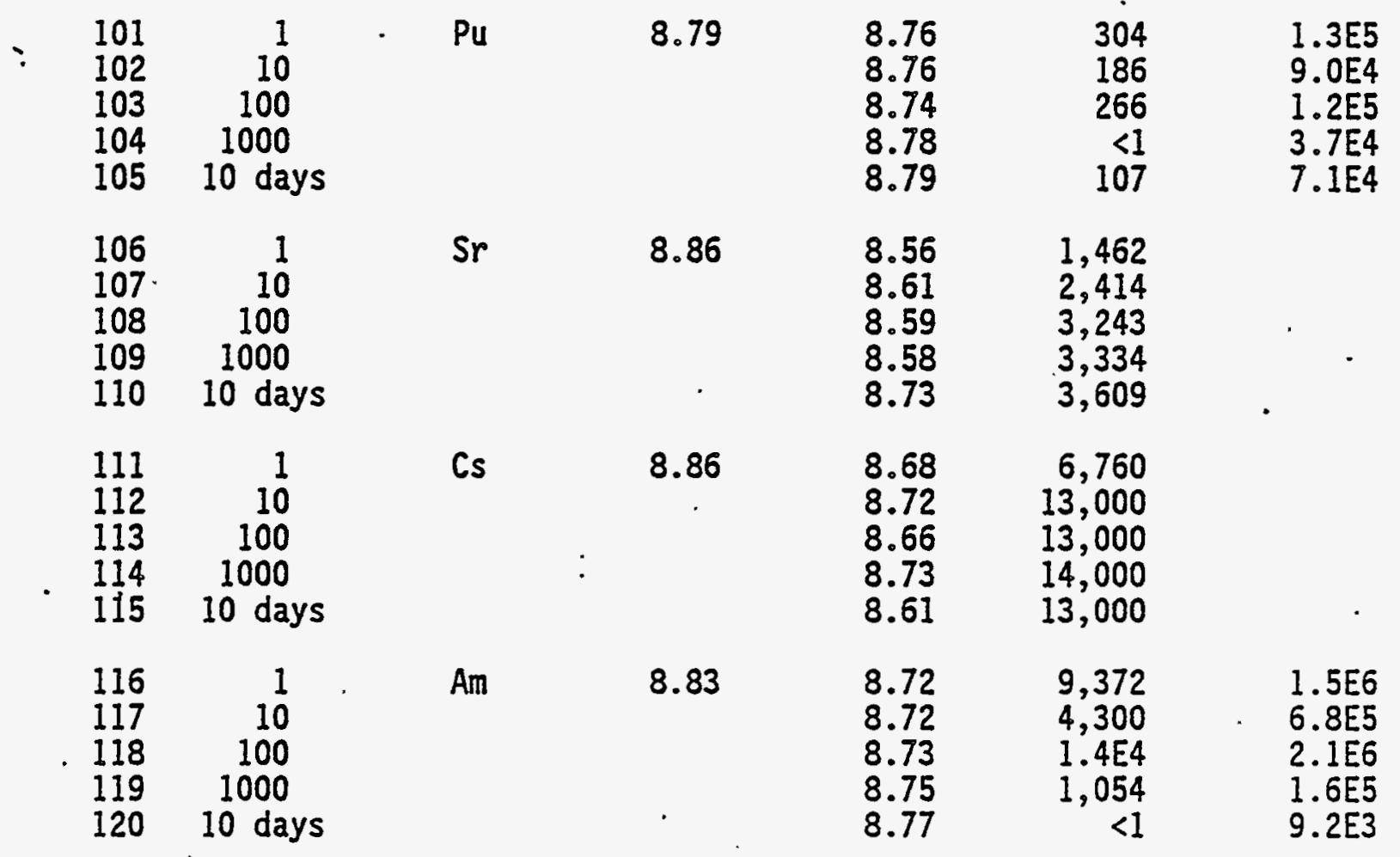

(a) Standard filtered and sample following contact filtered.

(b) Unfiltered standard and filtered sample following contact.

indicate that the TRU's are largely precipitated and that when filtered would result in a waste stream well under the criteria for being non-TRU. However, other TRU-containing waste streams with different compositions have been shown to have different TRU solubility values. For example, analysis of water washes of a7kaline sludge from Tank 8D-2 at West Valley Nuclear Services Co, Inc. (WVNS) have shown that "the Pu content at $\mathrm{pH} 12$ still represented approximately $5 \%$ of the $\mathrm{Pu}$ in the tank, exceeding the actinide 1 imit in the concrete waste form of $<100 \mathrm{nCi} / \mathrm{g}$ of waste" (Peterson et a1. 1989). This WVNS waste had high carbonate/bicarbonate content which was the expected reason for the high TRU solubility. The characterization of Neutralized Current Acid 
TABLE 7.7. Batch Distribution Ratios, $43.3^{\circ} \mathrm{C}$, Solution \#4, Nominal pH 11 №. Time, min Tracer Starting pH Final $p H \quad \underline{R}_{d}$ Value $^{(a)} \quad \underline{R}_{d} V_{a l u e^{(b)}}$

\begin{tabular}{|c|c|c|c|c|c|c|}
\hline $\begin{array}{l}121 \\
122 \\
123 \\
124 \\
125\end{array}$ & $\begin{array}{c}1 \\
10 \\
100 \\
1000 \\
10 \text { days }\end{array}$ & $\mathrm{Pu}$ & 10.43 & $\begin{array}{r}10.06 \\
10.07 \\
9.97 \\
9.94 \\
9.77\end{array}$ & $\begin{array}{r}230 \\
267 \\
226 \\
216 \\
1,033\end{array}$ & $\begin{array}{l}1.3 E 4 \\
1.2 E 4 \\
1.2 E 4 \\
1.2 E 4 \\
4.1 E 4\end{array}$ \\
\hline $\begin{array}{l}126 \\
127 \\
128 \\
129 \\
130\end{array}$ & $\begin{array}{c}1 \\
10 \\
100 \\
1000 \\
10 \text { days }\end{array}$ & Sr & 10.67 & $\begin{array}{r}10.01 \\
9.80 \\
9.93 \\
9.79 \\
9.90\end{array}$ & $\begin{array}{r}1,609 \\
2,393 \\
3,057 \\
3,260 \\
3,687\end{array}$ & \\
\hline $\begin{array}{l}131 \\
132 \\
133 \\
134 \\
135\end{array}$ & $\begin{array}{c}1 \\
10 \\
100 \\
1000 \\
10 \text { days }\end{array}$ & Cs & 8.86 & $\begin{array}{l}9.82 \\
9.96 \\
9.91 \\
9.84 \\
9.94\end{array}$ & $\begin{array}{r}5,700 \\
11,100 \\
12,200 \\
13,000 \\
11,800\end{array}$ & \\
\hline $\begin{array}{l}136 \\
137 \\
138 \\
139 \\
140\end{array}$ & $\begin{array}{r}1 \\
10 \\
100 \\
1000 \\
10 \text { days }\end{array}$ & Am & 10.62 & $\begin{array}{r}9.00 \\
10.08 \\
10.06 \\
9.97 \\
9.82\end{array}$ & $\begin{array}{r}124 \\
55 \\
162 \\
206 \\
361\end{array}$ & $\begin{array}{r}995 \\
651 \\
1,161 \\
1,320 \\
2,108\end{array}$ \\
\hline
\end{tabular}

(a) Standard filtered and sample following contact filtered.

(b) Unfiltered standard and filtered sample following contact.

Waste (NCAW) from double shel1 tank 101-AZ at Hanford showed supernate concentrations for ${ }^{241} \mathrm{Am}$ of $11 \mathrm{nCi} / \mathrm{g}$ and total $\mathrm{Pu}$ of $4.1 \mathrm{nCi} / \mathrm{g}$ at $\mathrm{pH} 13.7$ (Bray et a7. 1991). The composite of the water washes of the sludge had a total Pu content of $0.62 \mathrm{nCi} / \mathrm{g}$ at $\mathrm{pH}$ of 13.1. Aithough these values are well under the TRUTimit for grouting, they reflect differences from the values found in these current and previous "ion-exchange" tests which would indicate that both Am and $\mathrm{Pu}$ content would be well under $0.1 \mathrm{nCi} / \mathrm{g}$ above a.pH of 11 . Although these differences are probably due to differences in stream composition, it cannot be concluded that the TRU in actual SBS will be precipitated at levels such that the remaining solution would be non-TRU. Therefore, further investigations should be conducted to determine the TRU solubility under the more 
TABLE 7.8. Batch Distribution Ratios, $43.3^{\circ} \mathrm{C}$, Solution \#5, Nominal pH 12 №. Time, min Tracer Starting $p H$ Final $p H \quad R_{d} V_{a l u e}^{(a)} \quad R_{d}$ Value ${ }^{(b)}$

\begin{tabular}{|c|c|c|c|c|c|c|}
\hline $\begin{array}{l}141 \\
142 \\
143 \\
144 \\
145\end{array}$ & $\begin{array}{c}1 \\
10 \\
100 \\
1000 \\
10 \text { days }\end{array}$ & Pu & 11.86 & $\begin{array}{l}11.65 \\
11.68 . \\
11.64 \\
11.49 \\
11.31\end{array}$ & $\begin{array}{r}402 \\
551 \\
121 \\
48 \\
<1\end{array}$ & $\begin{array}{l}3.0 E 5 \\
3.8 \mathrm{EE} \\
1.4 \mathrm{EE} \\
9.5 \mathrm{E} 4 \\
5.1 \mathrm{E} 4\end{array}$ \\
\hline $\begin{array}{l}146 \\
147 \\
148 \\
149 \\
150\end{array}$ & $\begin{array}{c}1 \\
10 \\
100 \\
1000 \\
10 \text { days }\end{array}$ & Sr & 11.95 & $\begin{array}{l}11.41 \\
11.65 \\
10.35 \\
11.40 \\
11.48\end{array}$ & $\begin{array}{l}1,713 \\
2,714 \\
3,715 \\
6,105 \\
8,071\end{array}$ & \\
\hline $\begin{array}{l}151 \\
152 \\
153 \\
154 \\
155\end{array}$ & $\begin{array}{c}1 \\
10 \\
100 \\
1000 \\
10 \text { days }\end{array}$ & Cs & 11.93 & $\begin{array}{l}11.67 \\
11.65 \\
11.48 \\
11.49 \\
11.48\end{array}$ & $\begin{array}{r}5,420 \\
8,830 \\
10,900 \\
11,400 \\
11,700\end{array}$ & \\
\hline $\begin{array}{l}156 \\
157 \\
158 \\
159 \\
160\end{array}$ & $\begin{array}{c}1 \\
10 \\
100 \\
1000 \\
10 \text { days }\end{array}$ & Am & 11.90 & $\begin{array}{l}11.72 \\
11.68 \\
11.64 \\
11.55 \\
11.28\end{array}$ & $\begin{array}{l}78 \\
96 \\
<1 \\
<1 \\
<1\end{array}$ & $\begin{array}{l}4.5 \mathrm{E} 4 \\
4.9 \mathrm{E} 4 \\
8.6 \mathrm{E} 3 \\
9.5 \mathrm{E} 3 \\
5.4 \mathrm{E} 3\end{array}$ \\
\hline
\end{tabular}

(a) Standard filtered and sample following contact filtered.

(b) Unfiltered standard and filtered sample following contact.

representative conditions to be provided by actual radioactive bench-scale melter and SBS tests scheduled for FY-1994: These tests will produce a TRUcontaining SBS under more representative conditions than those which have been produced by "synthetic" chemical make-up methods. If additional TRU recovery is required beyond that provided by precipitation, it could likely be provided by the addition of TRU adsorbing zeolite such as A-50 (Bray et a1. 1990) or titanium-treated IE-96 (Bray et a1. 1991).

The $S r R_{d}$ values (Figure 7.1) and the $C s R_{d}$ values (Figure 7.2 ) show the effect of $\mathrm{pH}$ and contact time. In general the distribution values increase with contact time. The $C s R_{d}$ value rapidly approached equilibrium with the values measured at 100 minutes typical7y being about $95 \%$ of the final values 
TABLE 7.9. Batch Distribution Ratios, $43.3^{\circ} \mathrm{C}$, Solution $\# 6$, Nominal pH 13

\begin{tabular}{|c|c|c|c|c|c|c|}
\hline No. & Time, min & Tracer & Starting $\mathrm{pH}$ & Final $\mathrm{pH}$ & $\underline{R}_{d} V_{a l u e} e^{(a)}$ & $\underline{R}_{d}$ VaTue $^{(b)}$ \\
\hline $\begin{array}{l}161 \\
162 \\
163 \\
164 \\
165\end{array}$ & $\begin{array}{c}1 \\
10 \\
100 \\
1000 \\
10 \text { days }\end{array}$ & Pu & 12.92 & $\begin{array}{l}12.79 \\
12.85 \\
12.85 \\
12.84 \\
12.81\end{array}$ & $\begin{array}{r}7,471 \\
7,493 \\
1,140 \\
2,514 \\
.168\end{array}$ & $\begin{array}{l}7.9 \mathrm{E} 6 \\
7.8 \mathrm{E} 6 \\
1.3 \mathrm{E} 6 \\
2.7 \mathrm{E} 6 \\
2.8 \mathrm{E} 5\end{array}$ \\
\hline $\begin{array}{l}166 \\
167 \\
168 \\
169 \\
170\end{array}$ & $\begin{array}{c}1 \\
10 \\
100 \\
1000 \\
10 \text { days }\end{array}$ & sr & 12.97 & $\begin{array}{l}12.83 \\
12.88 \\
12.87 \\
12.85 \\
12.82\end{array}$ & $\begin{array}{r}960 \\
1,745 \\
3,394 \\
\cdot 18,432 \\
37,675\end{array}$ & \\
\hline $\begin{array}{l}171 \\
172 \\
173 \\
174 \\
175\end{array}$ & $\begin{array}{c}1 \\
10 \\
100 \\
1000 \\
10 \text { days }\end{array}$ & Cs & 12.94 & $\begin{array}{l}12.86 \\
12.89 \\
12.87 \\
12.85 \\
12.84\end{array}$ & $\begin{array}{l}2,440 \\
3,800 \\
3,860 \\
4,100 \\
4,279\end{array}$ & \\
\hline $\begin{array}{l}176 \\
177 \\
178 \\
179 \\
180\end{array}$ & $\begin{array}{c}1 \\
10 \\
100 \\
1000 \\
10 \text { days }\end{array}$ & Am & 12.95 & $\begin{array}{l}12.85 \\
12.87 \\
12.86 \\
12.85 \\
12.82\end{array}$ & $\begin{array}{r}2,684 \\
2,026 \\
1,148 \\
159 \\
<1\end{array}$ & $\begin{array}{l}3.4 \mathrm{E} 6 . \\
2.6 \mathrm{E} 6 \\
1.5 \mathrm{E} 6 \\
3.3 \mathrm{E} 5 \\
2.5 \mathrm{E} 4\end{array}$ \\
\hline
\end{tabular}

(a) Standard filtered and sample following contact filtered.

(b) Unfiltered standard and filtered sample following contact.

and even the 10 minute values typically about $90 \%$ of the final values. The $\mathrm{Sr}$ $R_{d}$ a7so increased rapidly with time reaching greater than $90 \%$ of the final values at $\mathrm{pH} 9$ and 11 within 100 minutes but continued to increase significantly with time at $\mathrm{pH}^{\prime} s 12$ and 13 . The $C s R_{d}$ values decrease with increasing $\mathrm{pH}$ (increasing sodium competition). The decline in $C S R_{d}$ was particulariy sharp between $\mathrm{pH} 12$ and 13 going from 11,700 to 4,279 as measured at 10 days reflecting the increase in $\mathrm{Na} / \mathrm{Cs}$ mole ratio from 187 to 480 . These results are similar to previous work (Bray 1990) and do not show degradation of the zeolite due to caustic attack of the aluminosilicate zeolite structure. There was no indication of physical degradation based on visual observations during the contact periods up to 10 days time and at all $\mathrm{pH}$ levels tested including 


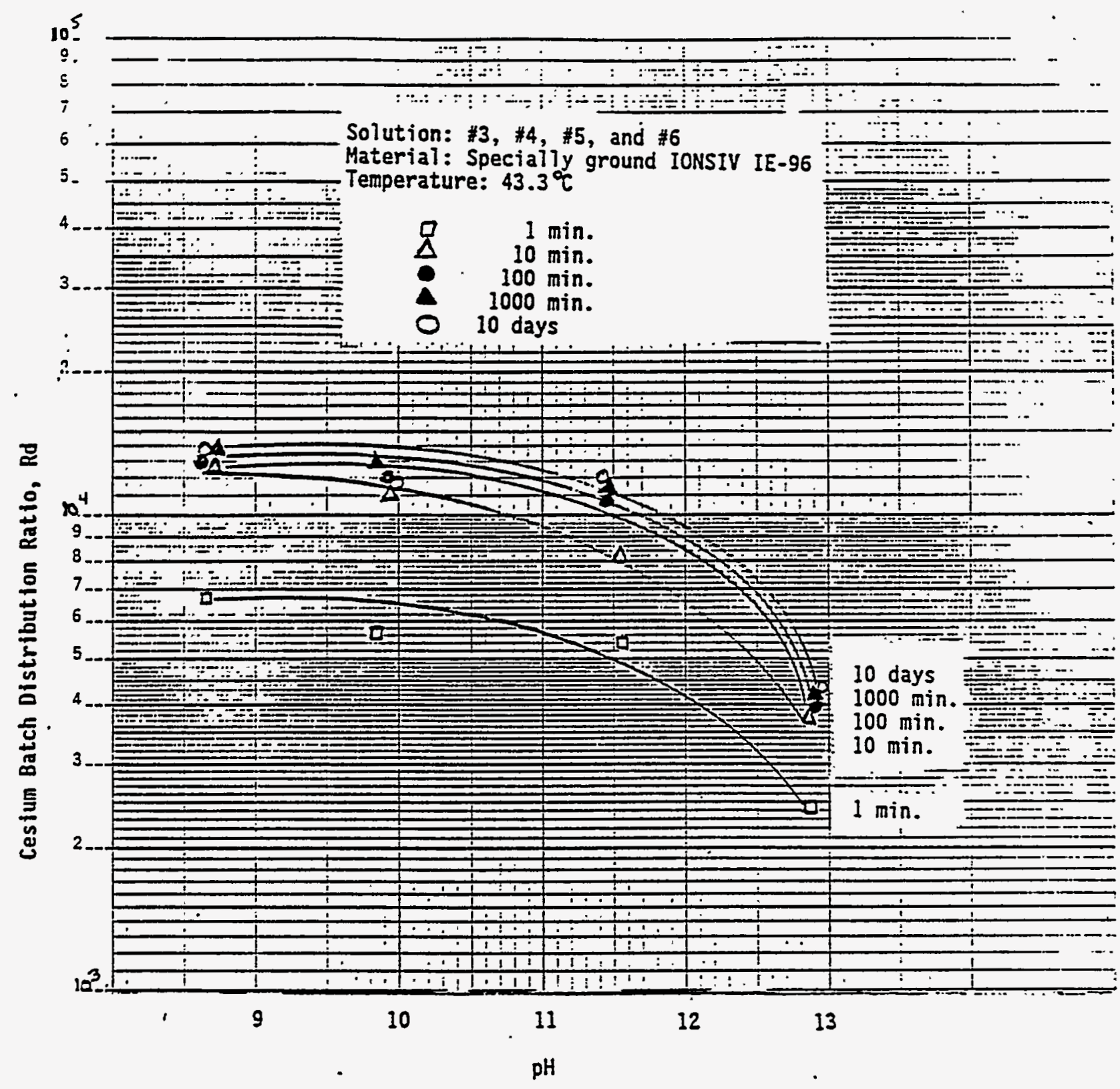

FIGURE 7.1. Cesium Distribution Ratio Values for Specially Ground IE-96 as a Function of Contact Time and $\mathrm{pH}$

$\mathrm{pH}$ 13. The visual inspections found no indication of zeolite breakdown to smaller particle size, agglomeration into gelatinous mass, or any other noticeable characteristics that could potentially cause problems in pumping, 


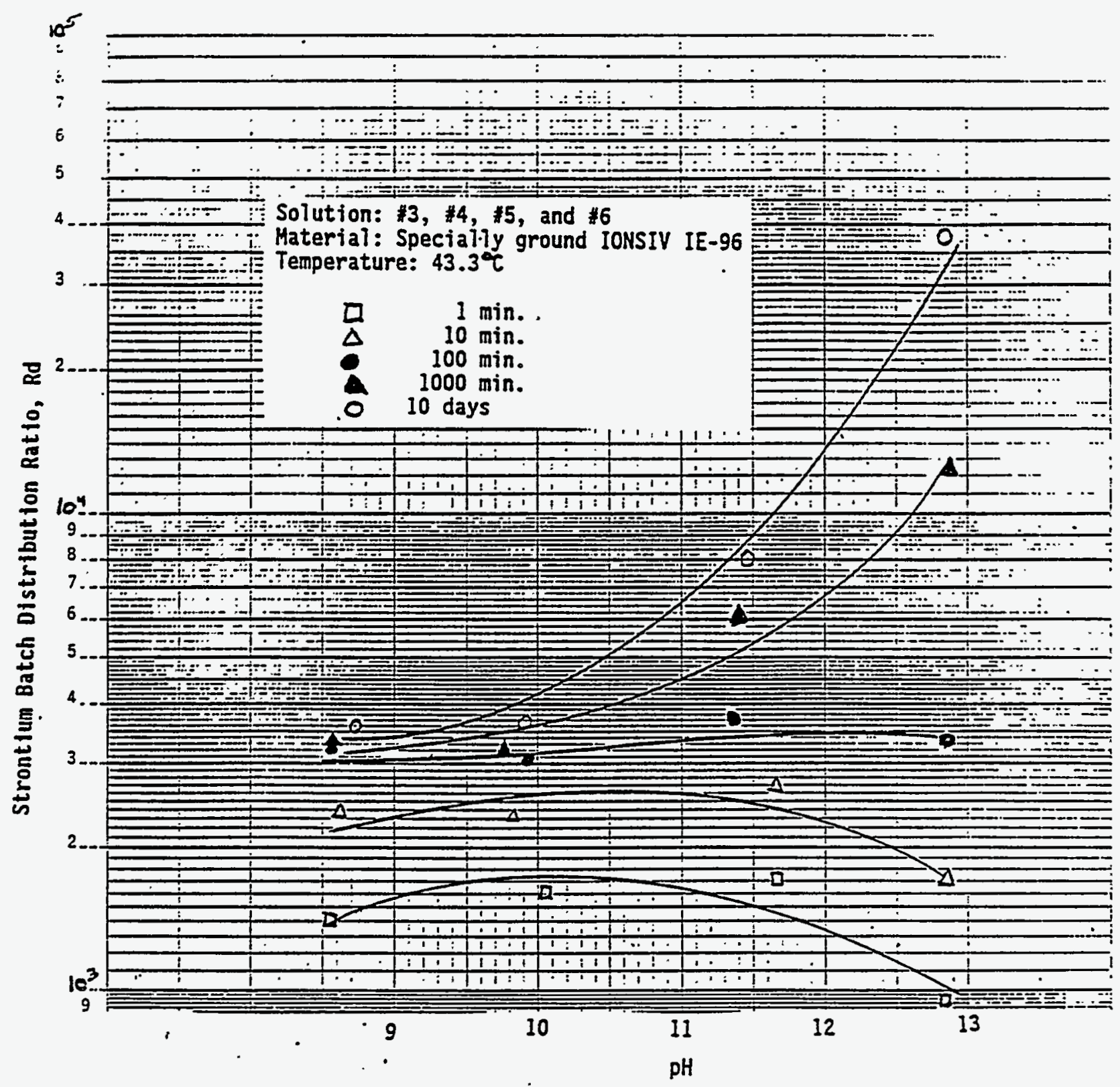

FIGURE 7.2. Strontium Distribution Ratio Values for Specially Ground IE-96 as a Function of Contact Time and $\mathrm{pH}$

filtering, or handling of the waste stream. Although these tests were conducted using the specially ground zeolite granules, there is no reason to expect that the previously used unbound zeolite crystals would degrade at high $\mathrm{pH}$ either. 
8.0 REFERENCES

Bray, L. A., R. J. Carson, K. J. Elovich, and D. E. Eakin. 1990. HWVP Transuranic Process Haste Treatment by Ion Exchange. HHVP-90-1.2.2.04.04A, Pacific Northwest Laboratory, Richland, Washington.

Bray, L. A., and F. T. Hera. July 1991. Use of Titanium-Treated Zeolite for Plutonium, Strontium, and Cesium Removal From West Valley Alkaline Wastes and Sludge Wash Haters. PNL-SA-19697 S. Pacific Northwest Laboratory, Rich7and, Washington.

Letter'R. A. Smith to J. M. Greer, "Zeolite Specification for Pacific Northwest Laboratory Testing Activities," 9152338, dated May 30, 1991.

Peterson, M. E., R. D. Scheele, and J. M. Tingly. September 1989.

Characterization of the -First Core Sample of Neutralized Current Acid Waste from Double Shell Tank 101-AZ. Pacific Northwest Laboratory; Rich land, Washington.

Sharp; S. D. 1988. Liquid Transuranic Haste Handling Final Study Report. FLU.V/HWVP-88-208, Fluor Daniel, Inc., Irvine, California.

8.1 
APPENDIX A

ZEOLITE PARTICLE SIZE ANALYSIS 


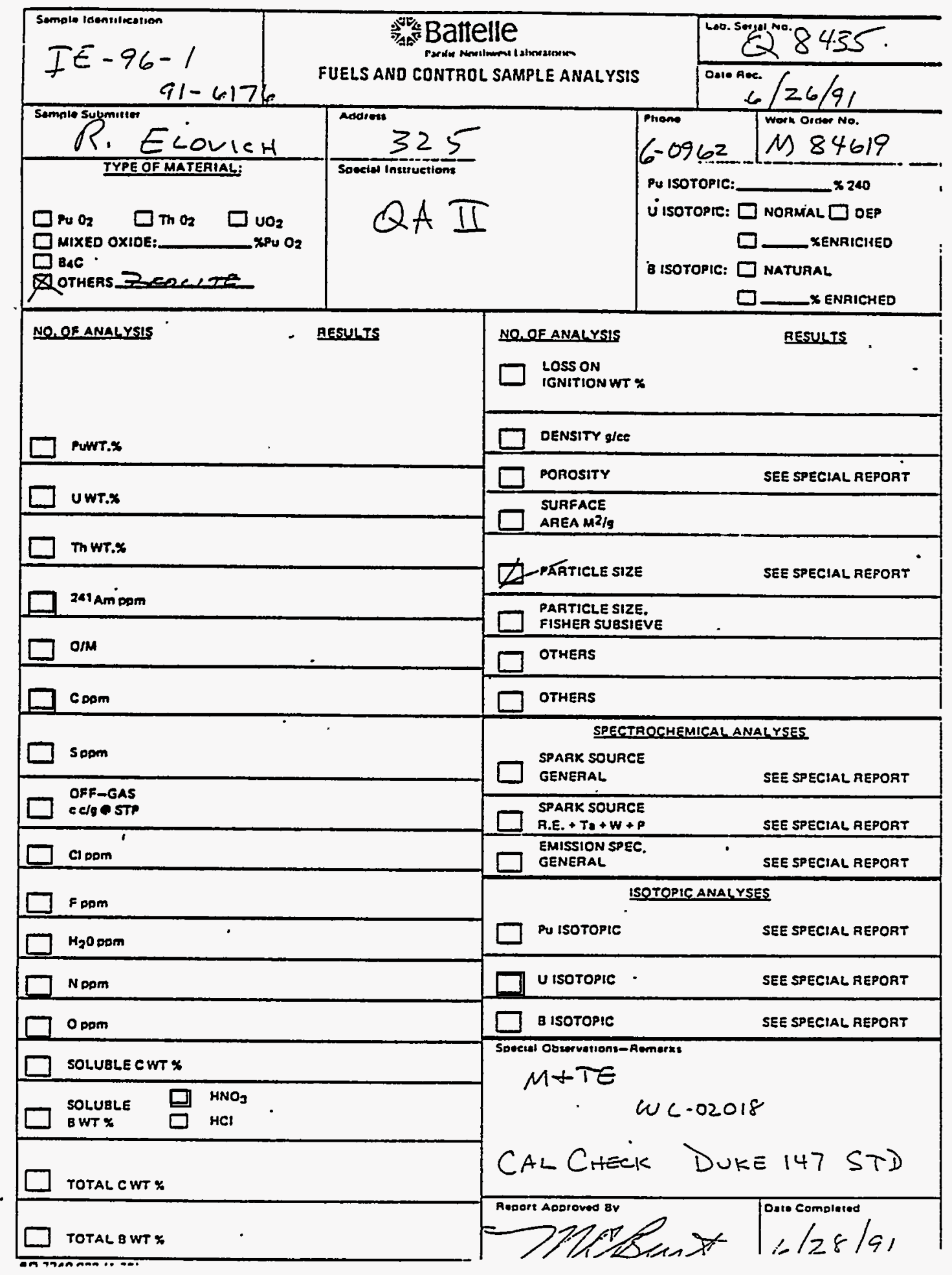

A. 1 


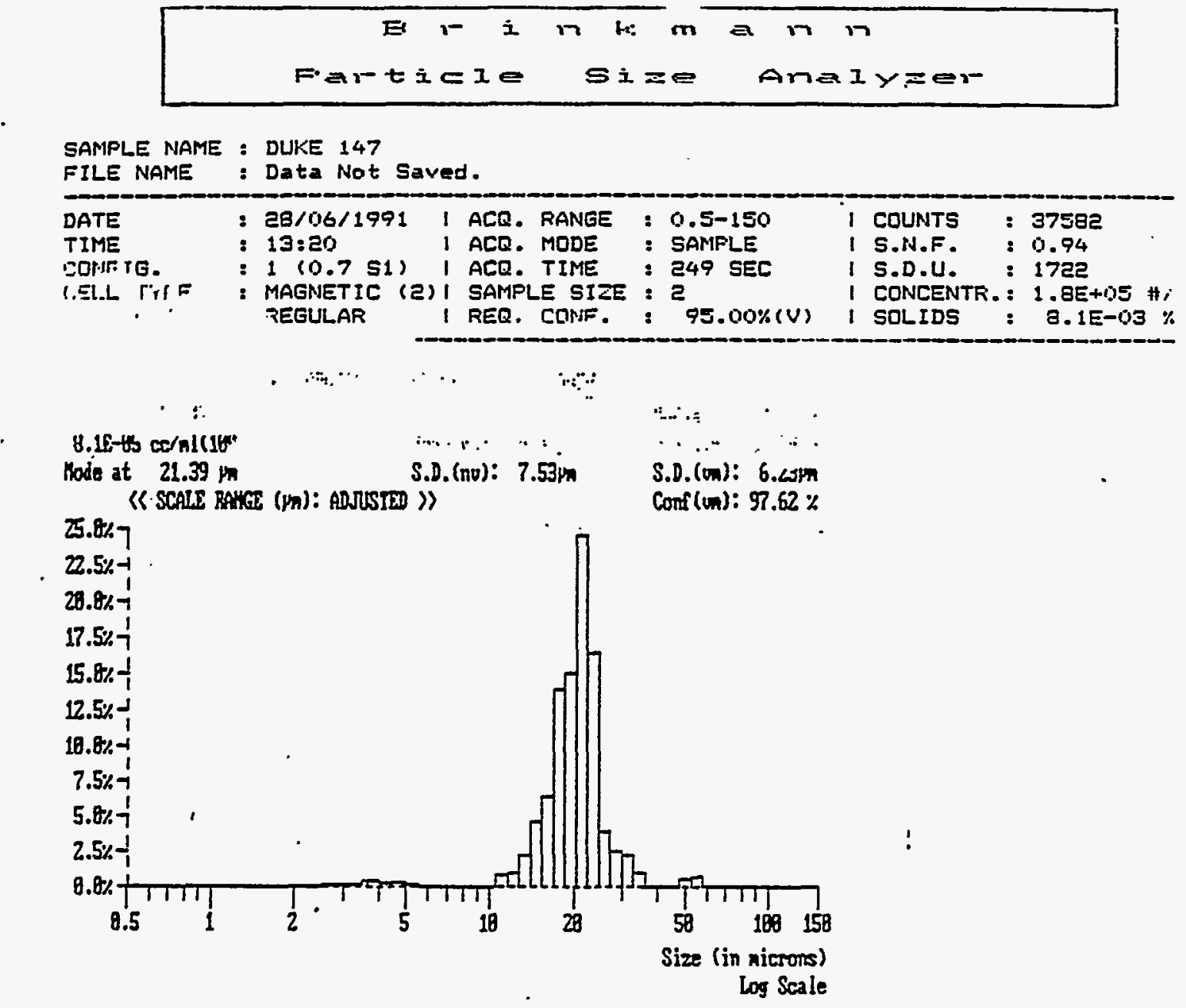

A. 2 


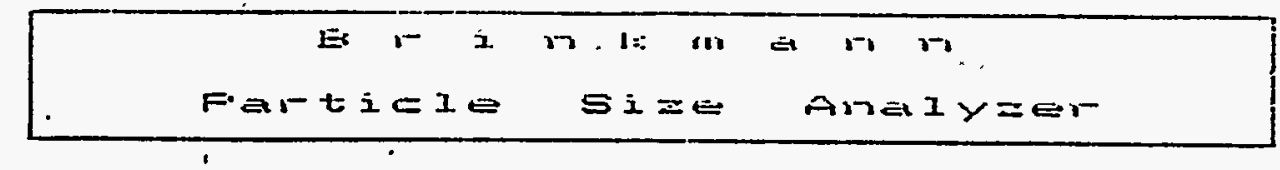

SAMFLE NAME : IE-96-1

FILE NAME : Data Hot Saved.

\begin{tabular}{|c|c|c|c|c|c|c|c|c|c|c|c|}
\hline $\begin{array}{l}\text { DATE } \\
\text { TIIHE } \\
\text { COINF IG. } \\
\text { CELL TYFE } \\
\text { SAMFLE TYFE }\end{array}$ & $\begin{array}{l}: \\
:\end{array}$ & $\begin{array}{l}28 / 06 / 1991 \\
13: 31 \\
1(0.751) \\
\text { MAGNETIC (2) } \\
\text { RiEGULAR }\end{array}$ & $\begin{array}{l}1 \\
1 \\
1 \\
1 \\
1\end{array}$ & $\begin{array}{l}\text { ACQ. } \\
\text { ACE. } \\
\text { ACQ. } \\
\text { SAIIFL } \\
\text { REG. }\end{array}$ & $\begin{array}{l}\text { RANGE } \\
\text { MODE } \\
\text { TINE. } \\
\text { E SIEE } \\
\text { COMF. }\end{array}$ & & $\begin{array}{l}\text { j.5- } 150 \\
\text { SAMFLE } \\
271 \text { SEC } \\
3 \\
95.00 \%(V)\end{array}$ & $\begin{array}{l}1 \\
1 \\
1 \\
1 \\
1\end{array}$ & $\begin{array}{l}\text { COUNTS } \\
\text { S.N.F. } \\
\text { S.D.U. } \\
\text { CONCENTF: } \\
\text { SOLIDS }\end{array}$ & $\begin{array}{r}: \\
\vdots \\
\vdots \\
: \\
:\end{array}$ & $\begin{array}{l}5403 i \\
0.58 \\
3247 \\
1.2 E+10 \# \\
5.7 E-03 \%\end{array}$ \\
\hline
\end{tabular}

PROBABILITY WOLWE DEYSITY GRAPH

Hame: IE-96-1

5.7E- $45 \mathrm{co/nl}(189.8 \%)$

Hode at $55.35 \mathrm{pt}$

(( SCALE RAHGE ( $\mathrm{m}$ ): ADJLSTED ))

Kean(nu): 4.47\%

S.D.(nu): $3.64 \mathrm{pm}$

. $15.8 \% 7$

$13.5 \%-1$

$12.8 \%-7$

$10.5 \%$ ?

$9.4 \% \frac{1}{1}$

$7.5 \%$

$6.8 \%-1$

$4.5 \%-7$

$3.8 \% 7$

$1.5 \% \frac{1}{1}$

$8.8 \%$ फा 8.5

\section{PPOBABILITY MUHBER DEYSITY GRAPH

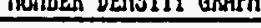

Hane: IE-96-1

$1.28+66 \mathrm{~V} / \mathrm{nl}(189.8 \%)$

Hode at $8.75 \mathrm{Hn}$

(C SCALE RAHGE ( $\left.\mu_{a}\right)$ : ADJUSTED 》

9.86\% 7

:.1 $x-1]$

$3.2 \times-1$

०. $3 \%$ ? ? ! !
Hedian : 48.52 $\mu_{\mathrm{x}}$

Heaniva): $48.18 \mathrm{~mm}$

S.D. (vm): 28.55p

Courf(un): $97.68 \%$

Hedian : 9.98pa

-Hean(ni): $1.27 \mathrm{pm}$

S.D. (inl): 1.76pr

Conf(ul): $183.98 \%$ 
$1, \cdot$

$1.0 \%-$

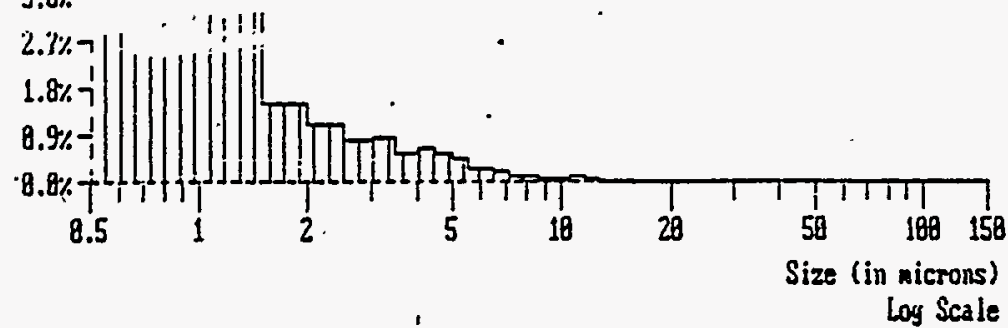

UQLUME DISTFIELITIQN TAFLE CEANIEESI

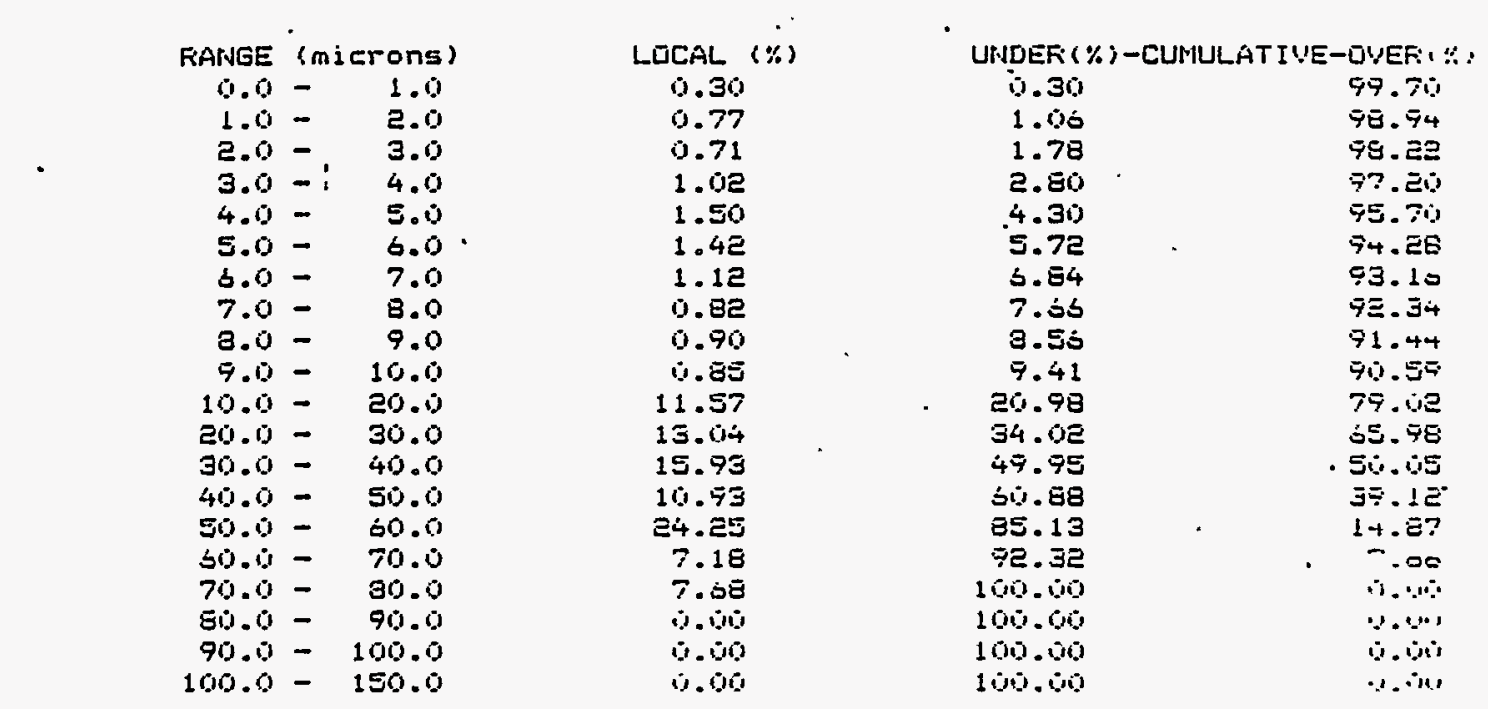

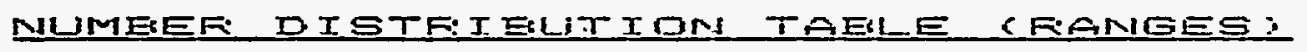

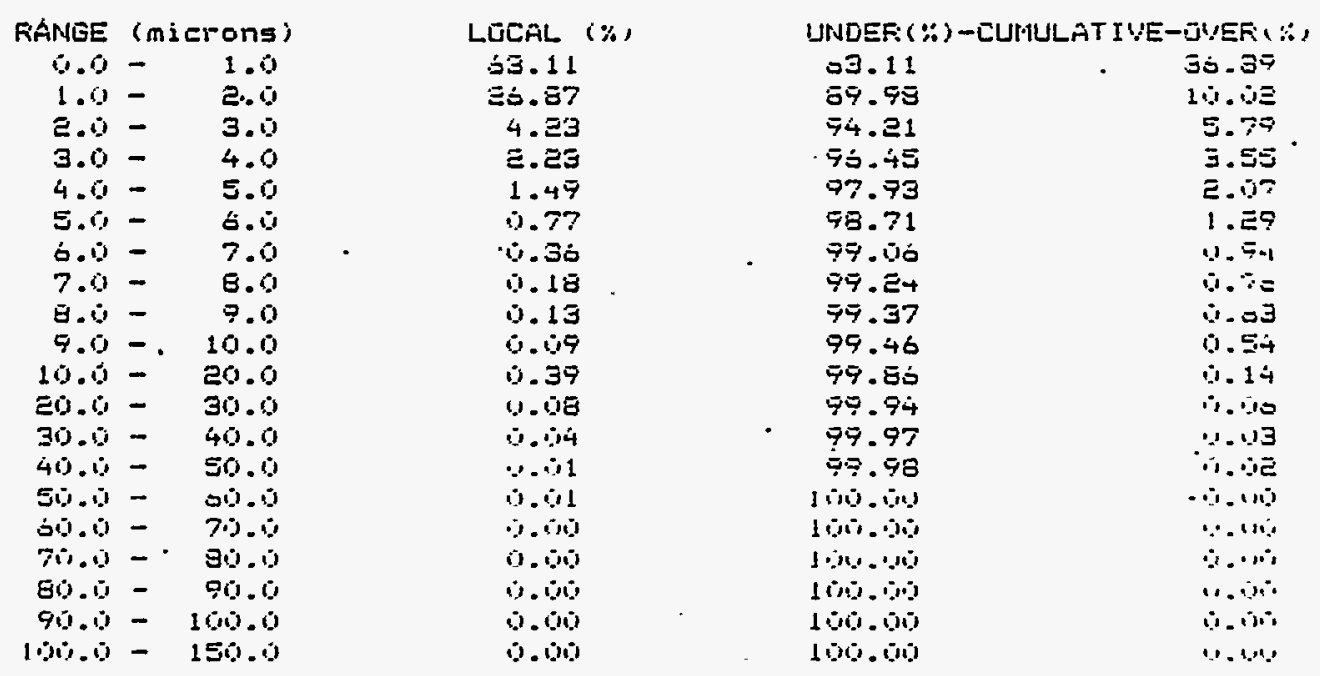

\section{A. 4}




\begin{tabular}{|c|c|c|c|}
\hline UHUSELS:: : & $=1-E$ & Buse, chltse, & WUER (\%) \\
\hline 5 & & 5.47 & i5 \\
\hline $1 \div$ & & 10.53 & 50 \\
\hline 15 & & 15.05 & 85 \\
\hline 20 & & 19.33 & 80 \\
\hline 25 & & 23.52 & 75 \\
\hline 30 & & 27.28 & 70 \\
\hline 35 & & 30.64 & 65 \\
\hline 40 & & 31.48 & 60 \\
\hline 45 & & 37.70 & 55 \\
\hline 50 & & 40.52 & 50 \\
\hline 55 & - & 47.95 & 45 \\
\hline 50 & & 48.52 & 40 \\
\hline 65 & . & s2.51 & 35 \\
\hline 70 & & 53.93 & 30 \\
\hline 75 & & 55.45 & 25 \\
\hline 85. & & 58.47 & 15 \\
\hline $90^{\circ}$ & & 59.53 & 10 \\
\hline 97 & & 74.43 & 3 \\
\hline 100 & & $80.0 \%$ & 0 \\
\hline
\end{tabular}

\section{NIMEEF DISTEIEIITIRN TAELE (FEFEENT)}

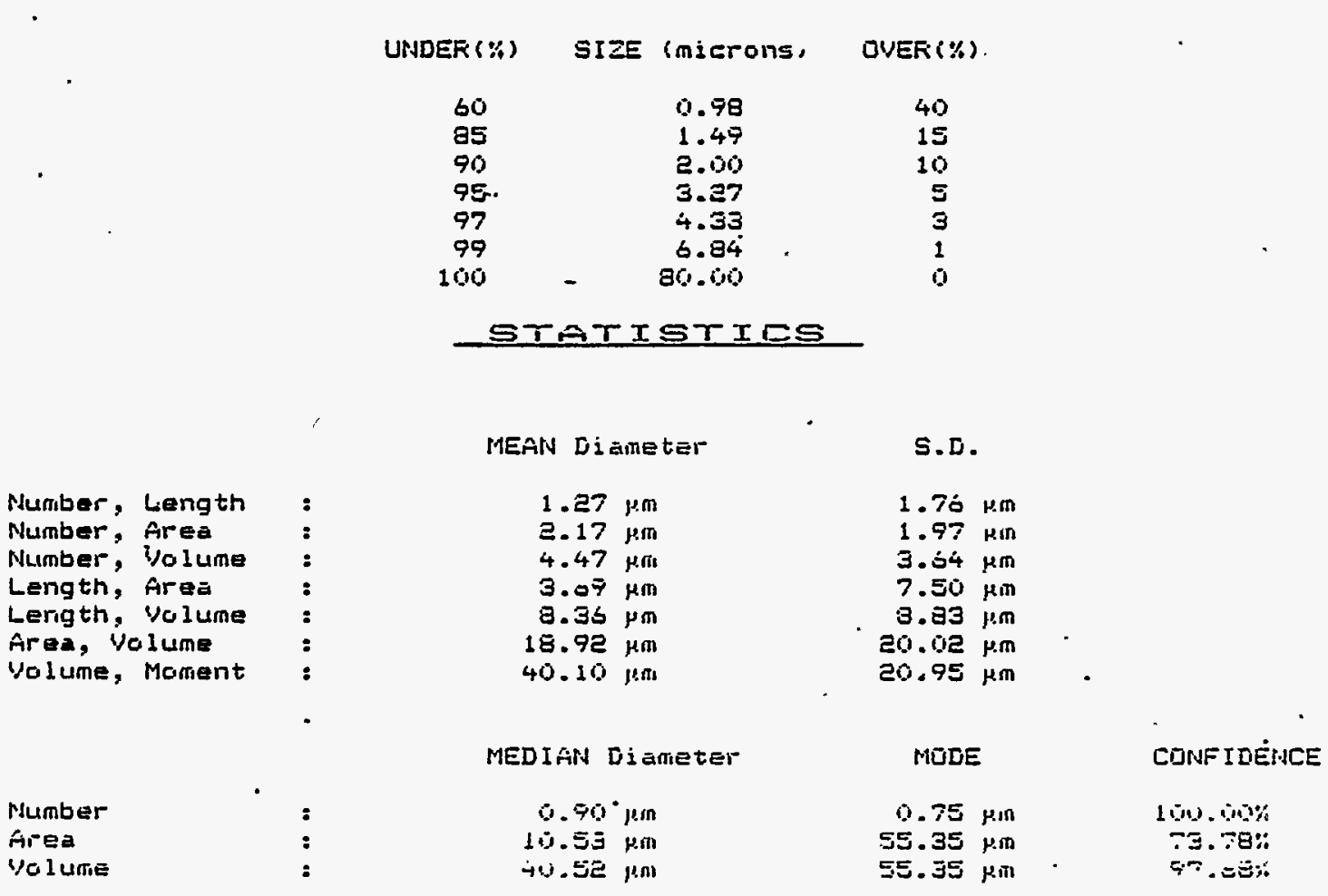

A.5 


\section{APPENDIX B}

\section{ZEOLITE STABILITY AT HIGH PH}


Date March 27, 1991

To DE Eakin

From MA Gerber

Subject Zeolite Stability at High PH

Attached is a draft of my review of the literature to determine the effect of high $\mathrm{pH}(\mathrm{w13})$ on the physical and chemical stability of IONOSIV-96 zeolite. 


\section{LINDE IONSIV-96 ZEOLITE ASSESSMENT}

A review of the literature was conducted to identify any information regarding the stability of Linde IONOSIV-96 zeolite in the high $\mathrm{pH}$ range. In earlier research by Bray et al. (1990) using zeolites to remove cesium and strontium from HWVP process waste streams it was concluded that the IONOSIV-96 was the best candidate for achieving the optimum residual levels of these radionuclides in the treated waste stream. It was recommended, however that the waste stream be maintained below a pH of 10 to prevent caustic attack of the aluminosilicate structure of the zeolite. There was no information in the report supporting this recommendation but there was extensive referencing of a report entitled Liquid Transuranic Waste Handling Final Study Report, prepared by Fluor Daniel for Westinghouse Hanford Company (WHC) (Sharp 1988).

Appendix $E$ of the Fluor Daniel report (Sharp 1988) contained a record of several phone conversations that discussed this potential problem. In a phone conversation dated $5 / 27 / 88$ between S. D. Sharp, the task leader for the report and D. Wallace, Savannah River, Mr. Hallace said that the zeolite may be sub- ject to caking if the $\mathrm{pH}$ of the contacting solution is too high. In a call between Mr. Sharp and Dennis Fennel1y, the representative for Union Carbide, manufacturer of IONOSIV-96. Mr. Fenneliy stated that zeolite agglomeration might occur if the $\mathrm{pH}$ of the contacting solution were greater than 10 , but that the phenomenon was also very dependent on the total chemical composition of the solution. He also said that at a pH lower than 5 the zeolite could be subject to dissolution via attack on the contained alumina again subject to specific solution chemistry.

I contacted Dennis Fennel1y by phone on $3 / 18 / 91$ to enquire about the stability of IE-96 in a high pH environment. He said that their experience was that at a pH of 12.5 or lower there was generally no problem. At higher $\mathrm{pH}$ there is a potential for loss of silica. He said that the best way to evaluate the phenomena was to analyze for silica content in the solution. He said that a consequence of silica loss was the potential for recrystallization of the zeolite causing agglomeration. He noted that this could lead to excessive pressure drop in an ion exchange column. He also noted that it was his

\section{B.1'}


opinion that the phenomenon took place over a period of days rather than hours, but was also dependent upon other operating. conditions such as temperature. I asked him if he knew of any published data on this phenomena and he said no. He mentioned the West Valley project as probably the closest in application.

I reviewed a report by Bray et al. (1984) that described the results of tests using zeolites to treat Hest Valley alkaline supernate. Zeolites tested included IONSIV-95 which, is very similar to IONSIV-96, differing only in the counter ions used (a mixture of calcium and sodium instead of predominantly sodium in the latter). Tests were conducted in batch and ion exchange column systems at $\mathrm{pH}$ values ranging from 10.4 to 13.6 and a $\mathrm{Na}+$ concentration of 7 M. Batch contact time was 8 days. Column contact times ranged from approximately 7 to 28 hours. There was no report of caking or agglomeration of the zeolite in these experiments.

A review of the literature on zeolites in general confirmed the fact that decomposition of the zeolite would probably occur at high pH but provided little information on either the rate or the mechanism. Sherman (1977) stated that zeolites are synthesized at elevated pH (e.g., pH 12 to 13+) and temperatures (e.g., $100^{\circ} \mathrm{C}$ to $300^{\circ} \mathrm{C}$ ) and are quite stable at conditions only slightly - Tess severe than those employed during their. synthesis. He stated that the chief restriction is their limited acid resistance, and that zeolites should not be employed below about pH 4-5 except for very brief exposures. operation above a $\mathrm{pH}$ of 6 is preferred.

MC Daniel and Maher (1976 p. 295) cite. a statement by Kunin (1960) that zeolites are unstable above a pH of about 8 and below a pH of about 6.5 in low silica water. They further state that zeolites have 1 imited.stability in acid media because of the loss of aluminum away from the structure. This is explained by the appreciable solubility of aluminum at a pH of 4 . Kunin noted that in the presence of hydrated silica the solubility is suppressed to a slightly lower pH. Liou and Donahoe (1984) say basically the same thing as . Kunin regarding the solubility of silica at high $\mathrm{pH}$; i.e., the addition of alumina to silica solutions shifts solubility towards a higher pH. 
Whether or not zeolites will recrystallize or only dissolve will largely depend upon the whether the silica and/or alumina achieve saturated conditions in the solution relative to the most stable zeolite under the exiting conditions. In addition to their own research on zeolite synthesis which was conducted at a pH of 13.35 to 13.71 and a silica concentration of $3.5 \mathrm{M} \mathrm{Liou} \mathrm{and}$ Donahoe (1984) cited other research by Jones et a1. (1977) Nordstrom et a7. (1978), and Hay $(1964,1966)$ in order to correlate the estimated silica content and $\mathrm{pH}$ of naturally alkaline bodies of water that contained aluminum and produced zeolites over time in the sediments. Specifically they correlate silica concentrations of $2 \times 10-2 \mathrm{M}$ at a $\mathrm{pH}$ of about 9.5 and $3.4 \times 10-4 \mathrm{M}$ at a pH of 8.5. For comparison the molar concentration of silica in the submerged bed scrubber (SBS) waste stream is projected to be $7.8 \times 10-3 \mathrm{M}$.

The literature was also reviewed to determine the effect of temperature on the stability of zeolites at high pH. Culfaz and Sand (1973) conducted experiments on the mechanisms of both nucleation and crystallization of zeolites from gels. Their research results on the crystallization of mordenite showed that increasing the temperature of the solution from 90 to $120^{\circ} \mathrm{C}$ increased the crystal growth rates by more than factor of 3.5. Mariner (1970), research results showed an acceleration in the rate of zeolite mineral alteration with temperature although specific rates cannot be calculated from his results.

One important consideration noted in the literature on synthesizing zeolites was the dependence of the Si/AI ratio of zeolites on the solution $\mathrm{pH}$. Liou and Donahoe (1984) showed that the pH of the solution is the primary control on the Si/Al ratio of precipitated zeolites with higher $\mathrm{pH}$ producing zeolites with a lower Si/Al molar ratio. Their experimental data using a solution with a Si concentration of $3.5 \mathrm{M}$ achieved a variation in the zeolite Si/AT ratio of 2.19 to 1.81 corresponding to a variation in $\mathrm{pH}$ of 13.35 to 13.71. In these experiments the Si//Al ratio in the solution ranged from about 61 to 72. However in experiments conducted at a constant pH of 13.67, there was no significant variation in the Si/Al ration for the synthesized zeolites $(\mathrm{Si} / \mathrm{AT}=1.86 \pm 0.01)$ even though the $\mathrm{Si} / \mathrm{Al}$ in the solution in these experiments varied from 69 to 92 . Based on these results and the research of 
others they predict that a solution containing $3.4 \times 10-5 \mathrm{M} \mathrm{Si}$ the Si/Al molar ratio decreases from about 2.1 to about 1.4 as the $\mathrm{pH}$ of the solution is increased from 10 to 13 .

There is also experimental evidence that over a period of time zeolites will alter to more thermodynamically stable structures. Mariner and Surdam (1970) conducted experiments on the dissolution of rhyolite glass (Si/Al of 6.5 and $\mathrm{Na} / \mathrm{Al}$ of 1.2 ) and subsequent recrystallization to produce zeolites. In these experiments the glass was dissolved at $80^{\circ} \mathrm{C}$ for 70 days in solutions ranging from a pH of 9.1 to 11.5. The solution was then cooled for 24 hours to produce sodium aluminosilicate gels and then reheated to $80^{\circ} \mathrm{C}$ for 2 weeks. The resulting zeolites had Si/Al ratios decreasing from 3.4 to 2.2 over the $\mathrm{pH}$ range. Experiments conducted by Bosmans et al. (1973) showed that significant structural changes in zeolites can be achieved in a matter of days at solution temperatures of about $90^{\circ} \mathrm{C}$.

Based on the above review it appears that at a pH of 13 the zeolite will want to decompose. However, the decomposition rates will likely be very slow and not manifest itself to any significant degree over the time period to be examined. It also appears that because the zeolite is has a relatively high - Si/Al ratio and the fact that the amount of silica in solution will be below the saturation point at this $\mathrm{pH}$; that silica dissolution will be the most likely indicator of decomposition. Aluminum may also dissolve, but it is expected to be a much lower rate than the silica. The impact of zeolite decomposition on the adsorption of cesium is uncertain. The aluminum in the zeolite is responsible for creating the cation adsorption site on the silica because of the imbalance of charge introduced by its lower oxidation state $(+3$ vs. +4 for silica). Consequently the total adsorption capacity of the zeolite would only decrease as the aluminum dissolves. However, there is a general trend in zeolites to lose selectivity. towards Cesium as the Si/Al ratio decreases (Kirk-Othmer 1981, Kano and Mimura 1984). This latter affect would be in addition to any decrease in selectivity due solely to increased $\mathrm{pH}$.

Based on these conclusions it is recommended that analysis silica concentration in the solution be monitored with time in addition to visual observations for evidence of caking or agglomeration for evidence of decomposition. 
Evaluation of cesium concentration in solution should also be performed in order to correlate any observed decomposition to loss of selectivity or adsorption capacity for cesium. Because of the stated threshold for instability at a pH of about 12.5 according to Dennis Fenne17y the IONSIV-96 representative for Union Carbide, it is recommended that at least limited (short to intermediate duration) testing be conducted at a $\mathrm{pH}$ of about 12 as a potentially more practical maximum pH value for operations.

\section{REFERENCES}

Bosmans, H. J., E. Tambuyzer, J. Paenhuys, L. Ylen and J. vanCluysen. 1973. "Zeolite Formation in the System $\mathrm{K}_{2} \mathrm{O}-\mathrm{Al}_{2} \mathrm{O}_{3}-\mathrm{SiO}_{2}-\mathrm{H}_{2} \mathrm{O}$." Molecular Sieves Advances in Chemistry Series 1 1, eds. H. M. Meier, and J. B. Uytterhoeven. American Chemical Society. Washington D. C.

Bray, L. A., L. K. Hotton, T. R. Myers, G. M. Richardson, B. M. Wise. 1984. Experimenta1 Data Developed to Support the Selection of a Treatment Process for Hest val7ey A7kal ine Supernatant, PNL-4969, Pacific Northwest Laboratory, Richland Washington.

Bray, L. A. , K. J. Carson, R. J. Elovich, D. E. Eakin. 1990. HWVP Transuranic Process Waste. Treatment by Ion Exchange, HWVPg0-1.2.2.04.04A, Pacific Northwest (note: limited distribution report).

.Culfaz, A. and L. B. Sand. (1973). "Mechanism of Nucleation and Crystallization of ZeoTites from Gels." in Molecular Sieves, Advances in Chemistry Series 121, Chapter 11. Meyer and Uytterhoeven eds. American Chemical Society, Washington D. C.

Hay, R. L. 1966. "Phillipsite of Saline Lakes and Soils. American Mineral, $40: 1366-1387$.

Jones, B. F., H. P. Eugster and S. L. Rettig. 1977. "Hydrochemistry of the. Lake Magadi Basin, Kenya," Geochim. Cosmochim. Acta, 41, 53-72

Kanno T. and H. Mimura. 1984. "Ion Exchange Properties of Zeolites and Application to Processing of High - Level Liquid Waste, "Technical Committee Meeting Inorganic Ion Exchangers and Adsorbents for Chemical Processing in the Nuclear Fuel Cycle, June 12-15, Vienna. IAEA TC-518/20, International Atomic Energy Agency. Note: this is a Preprint and not referenceable with out checking final report.

Kirk, R. E. and D. F. Othmer, eds. 1981. "Molecular Sieves." Vol. 2 of Encyclopedia of Chemical Technology, John Wiley and Sons, Inc., New York.

Kunin, R. 1960. Elements of Ion Exchange, Reinhold Pub7ishing Corp., New York. P. 25: 
Liou, J. G. and R. J. Donahoe. 1984. The Mechanism of Zeolite Crystallization: and Thermochemical Properties of Some Synthetic Zeolites; DOE/ER/12051--T1, U.S. Department of Energy, Hashington D. C.

Mariner, R. H. and R. C. Surdam. 1970. "Alkal inity and Formation of Zeolites in Saline Alkaline Lakes." Science, 170:977-980.

Mc Daniel, C. V., and P. K. Maher. 1976. "Zeolite Stability and Ultrastable Zeolites," Chapter 4 in Zeolite Chemistry and Catalys is ASC Monograph No 171. JuTe A. Rabo, Ed. American Chemical Society, Hashington D. C.

Nordstrom, D. K., L. N. Plummer, T. M. Higley, T. J. Wolery and others. 1978. "A Comparison of Computerized Chemical Models for Equilibrium Calculations in Aqueous Systems," In Chemical Modeling in Aqueous Systems, ed. A. J. Jenne, p. 857-892. American Chemical Society Symposium Series 93.

Sharp, S. D. 1988. Liquid Transuranic Haste Handling Final Study Report CWBS 3706 (SOW 5.3.7.6), FLU>V/HWVP-88-208(FRF-535): Flour Daniel, Inc., Irving, California. (Note: this is probably not referenceable).

Sherman, J. D. 1978: "Ion Exchange Separations With Molecular Sieve

Zeolites," in Adsorption and Ion Exchange Separations AICHE Symposium Series 179, vol. 74, American Institute of Chemical Engineers, Tarrytown, New York. 